\title{
Rules, Standards, and Experimentation in Appellate Jurisdiction
}

\author{
BRYAN LAMMON*
}

TABLE OF CONTENTS

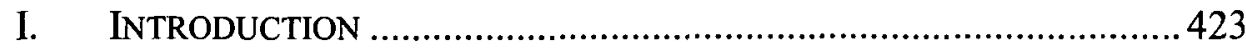

II. REFORM AND CONSEQUENCES IN INTERLOCUTORY APPEALS ........ 428

A. The Final Judgment Rule and Its Exceptions ........................ 428

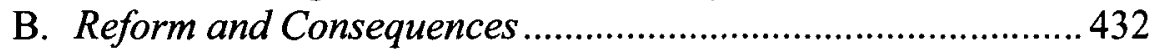

III. JUDICIAL EXPERIMENTATION AND STANDARDS .............................436

A. Judicial Experimentation in Interlocutory Appeals ................. 437

B. Standards in Transition ..........................................................44 44

C. Standards and Multi-court Experimentation ........................... 444

IV. EXPERIMENTING WITH A REIMAGINED COLLATERAL ORDER

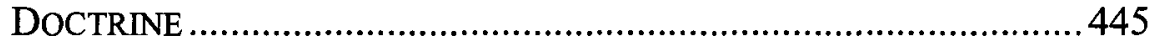

A. The Inadequacy of the Current Collateral Order

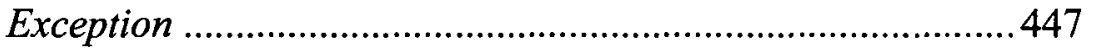

B. Relaxing the Collateral Order Requirements ........................452

C. Percolating Procedure and Jurisdiction.................................459

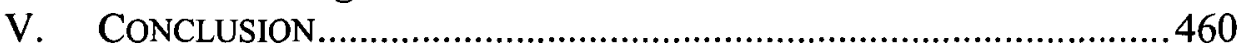

\section{INTRODUCTION}

The United States courts of appeals generally have jurisdiction over only "final decisions" by a district court. ${ }^{1}$ Most litigants must therefore wait until the end of proceedings in the district court-when all issues have been decided and all that remains is executing the judgment--before they can appeal. ${ }^{2}$ But not always. In fact, a whole slew of judicial, legislative, and rule-based exceptions permit an appeal before final judgment. And by nearly all accounts, this system of interlocutory appellate review is a mess; the exceptions are so many, the requirements so vague, and the judicial treatment so inconsistent that the regime is too complicated and too unpredictable. ${ }^{3}$

*Visiting Assistant Professor, Washington University School of Law. Thanks to Scott Baker, Rebecca Hollander-Blumoff, Deborah Dinner, Pauline Kim, Ron Levin, Julian Lim, Greg Magarian, Laura Rosenbury, Kent Syverud, and participants in the Washington University Junior Faculty Workshop.

128 U.S.C. $\S 1291$ (2006).

2 See Catlin v. United States, 324 U.S. 229, 233 (1945) (defining a "final decision" as one that "ends the litigation on the merits and leaves nothing for the court to do but execute the judgment").

${ }^{3}$ See, e.g., Adam N. Steinman, Reinventing Appellate Jurisdiction, 48 B.C. L. REV. $1237,1238-39$ (2007) (cataloguing criticisms of the current interlocutory appeal system). 
The system of appellate jurisdiction over non-final district court orders has thus been a persistent target of reform efforts, ${ }^{4}$ and the matter continues to be one of "the most troublesome issues in civil procedure."5 No one strongly defends the status quo, and proposed reforms generally fall into one of two camps. One camp advocates a system of clear categorical rules defining what

${ }^{4}$ See Lloyd C. Anderson, The Collateral Order Doctrine: A New "Serbonian Bog" and Four Proposals for Reform, 46 DRAKE L. REV. 539, 606-14 (1998); Thomas J. André, Jr., The Final Judgment Rule and Party Appeals of Civil Contempt Orders: Time for a Change, 55 N.Y.U. L. REV. 1041, 1080-84, 1108 (1980); Paul D. Carrington, Toward a Federal Civil Interlocutory Appeals Act, L. \& CONTEMP. PROBS., Summer 1984, at 165, 166-70; Edward H. Cooper, Timing as Jurisdiction: Federal Civil Appeals in Context, L. \& CONTEMP. ProBS., Summer 1984, at 157, 163-64; Carleton M. Crick, The Final Judgment as a Basis for Appeal, 41 YALE L.J. 539, 563-65 (1932); Howard B. Eisenberg \& Alan B. Morrison, Discretionary Appellate Review of Non-Final Orders: It's Time To Change the Rules, 1 J. APP. PRAC. \& PROCESS 285, 293-302 (1999); Kristin B. Gerdy, "Important" and "Irreversible" but Maybe Not "Unreviewable": The Dilemma of Protecting Defendants" Rights Through the Collateral Order Doctrine, 38 U.S.F. L. REV. 213, 256-60 (2004); Timothy P. Glynn, Discontent and Indiscretion: Discretionary Review of Interlocutory Orders, 77 Notre DAmE L. REV. 175, 258-67 (2001); Lawyers Conference Comm. on Fed. Courts \& the Judiciary, The Finality Rule: A Proposal for Change, 19 JUDGES' J., no. 3, 1980 at 33, 35-38; Robert J. Martineau, Defining Finality and Appealability by Court Rule: Right Problem, Wrong Solution, 54 U. PITT. L. REV. 717, 748-87 (1993); Aaron R. Petty, The Hidden Harmony of Appellate Jurisdiction, 62 S.C. L. REv. 353, 393-405 (2010); James E. Pfander \& David R. Pekarek Krohn, Interlocutory Review by Agreement of the Parties: A Preliminary Analysis, 105 Nw. U. L. REv. 1043, 1058-81 (2011); Andrew S. Pollis, The Need for Non-Discretionary Interlocutory Appellate Review in Multidistrict Litigation, 79 FORDHAM L. REV. 1643, 1685-93 (2011); Cedric W. Porter, Appeals from Interlocutory and Final Decrees in the United States Circuit Courts of Appeal, 19 B.U. L. REv. 377, 411-12 (1939); Martin H. Redish, The Pragmatic Approach to Appealability in the Federal Courts, 75 Colum. L. REV. 89, 124-27 (1975); Cassandra Burke Robertson, Appellate Review of Discovery Orders in Federal Court: A Suggested Approach for Handling Privilege Claims, 81 WaSH. L. REV. 733, 777-85 (2006); Thomas D. Rowe, Jr., Defining Finality and Appealability by Court Rule: A Comment on Martineau's "Right Problem, Wrong Solution," 54 U. PITT. L. REV. 795, 797-803 (1993); Michael E. Solomine \& Christine Oliver Hines, Deciding to Decide: Class Action Certification and Interlocutory Review by the United States Courts of Appeals Under Rule 23(f), 41 WM. \& MARY L. REV. 1531, 1562-72 (2000); Michael E. Solimine, Revitalizing Interlocutory Appeals in the Federal Courts, 58 GEO. WASH. L. REV. 1165, 1201-03 (1990); Steinman, supra note 3, at 1276-94; Melissa A. Waters, Common Law Courts in an Age of Equity Procedure: Redefining Appellate Review for the Mass Tort Era, 80 N.C. L. REv. 527, 584-602 (2002); Brad D. Feldman, Note, An Appeal for Immediate Appealability: Applying the Collateral Order Doctrine to Orders Denying Appointed Counsel in Civil Rights Cases, 99 GEO. L.J. 1717, 1739-44 (2011); Theodore D. Frank, Comment, Requiem for the Final Judgment Rule, 45 TEX. L. REV. 292, 320 (1966); Michael W. McConnell, Comment, The Appealability of Orders Denying Motions for Disqualification of Counsel in the Federal Courts, 45 U. CHI. L. REV. 450, 48182 (1978); John C. Nagel, Note, Replacing the Crazy Quilt of Interlocutory Appeals Jurisprudence with Discretionary Review, 44 DUKE L.J. 200, 214-22 (1994).

${ }^{5}$ Steinman, supra note 3 , at 1237. 
can be appealed and when; ${ }^{6}$ the other proposes a system of appellate court discretion over whether to hear an interlocutory appeal. ${ }^{7}$

The debate between these two camps is at something of a stalemate, as much of it occurs at an unhelpfully abstract level that has little grounding in evidence. The debate is largely about consequences-about the effect of proposed reforms on courts and litigants. The two sides generally agree on what effects are relevant. But they disagree about the likely effects of proposed reforms. For example, the sides disagree about whether a discretionary regime would increase appellate workloads. Advocates of rules argue that discretion would inevitably and substantially increase the number of appeals; advocates of discretion counter that it would not, with some even suggesting that appellate workloads would actually decrease. ${ }^{8}$ Another example is the disagreement about the flexibility of categorical rules. Advocates of discretion contend that a system of categorical rules would not be sufficiently flexible to accommodate unanticipated situations; rule advocates say that it would..$^{9}$

Similar disagreements about the actual effects of any proposed reform can be found throughout the literature. And these disagreements largely concern the observable effects of proposed reforms. The camps dispute whether a discretionary system would create more work-and, if it did, how much more work-as well as the more value-laden argument about whether that work is "too much"; they dispute how flexible a rule-based system would be and whether that flexibility would be "sufficient."

To the extent the debate over interlocutory appeal reform addresses the potential effects of proposed reforms, it lacks substantial evidence on those matters. Commentators instead implicitly rely on assumptions about how litigants and judges would respond to the proposed reform. Arguments about consequences-based primarily on reason, theory, and behavioral assumptions-dominate the debate. These assumptions are reasonable, but each side's assumptions often conflict with the other's. And the literature offers no way for determining which of two conflicting assumptions is more likely to be accurate. Disagreement thus occurs at both empirical and evaluative levels; the two sides can disagree over how much appeals would increase under a discretionary regime and whether that amount is "too much." A means of determining the actual consequences of various approaches to interlocutory appeals could go a long way toward breaking the current stalemate.

${ }^{6}$ See, e.g., Glynn, supra note 4, at 259.

${ }^{7}$ See, e.g., Cooper, supra note 4, at 164; Eisenberg \& Morrison, supra note 4, at 301; Martineau, supra note 4, at 776-77.

${ }^{8}$ Compare Glynn, supra note 4 , at 238 (arguing that a discretionary system would increase the number of appeals), with Eisenberg \& Morrison, supra note 4, at 301-02 (arguing that a discretionary system might decrease the total number of appeals).

${ }^{9}$ Compare Cooper, supra note 4, at 157 (arguing that a system of rules cannot capture the complexity of timing appeals), Martineau, supra note 4, at 775 (same), and Nagel, supra note 4, at 216 (same), with Glynn, supra note 4, at 261 (contending that rulemaking could be flexible). 
In this Article, I argue that an experimental approach to interlocutory appeals, initiated and overseen by judges, would solve much of this problem. Part II sets up the issue. First, it addresses the common cost-benefit calculus for determining whether and when to allow an immediate appeal. Conflicting interests of efficiency and error correction underlie discussions of appeals, and both the final judgment rule and its exceptions reflect efforts to strike a reasonable balance between these two interests. Part II then briefly reviews the current state of the law, highlighting the final judgment rule and its exceptions. Finally, I demonstrate the overly abstract nature of the current reform debate, which is a product of largely consequentialist argumentation that lacks evidence about the actual consequences of proposed reforms.

Part III begins by showing that judicial experimentation, sometimes called "percolation," would likely work in the context of interlocutory appeals; federal courts have both the incentives and the ability to conduct this type of experimentation, and the costs of judicial experimentation are probably lower in this context. Part III then explores, at a general level, one means of conducting judicial experimentation - the use of standards in a hierarchical court system. The rules and standards literature has often noted that standards can facilitate judicial learning, giving courts a way to gather information about what facts might be relevant when crafting a rule. ${ }^{10}$ In a hierarchical system like the federal judiciary, the adoption of a standard by an upper court might also facilitate judicial experimentation by encouraging multiple lower courts to take divergent approaches to a single legal issue. Simultaneous and repeated application of those divergent approaches would then generate evidence as to their consequences, allowing courts to then compare the observable effects of those approaches.

Part IV sets out one feasible way by which experimentation could occur in this context. My proposed reform is modest and suggests tweaking one of the existing judicial exceptions to the final judgment rule, the collateral order

${ }^{10}$ The rules and standards literature has made few inroads into discussions of jurisdiction; only recently have commentators begun explicitly exploring the values of rules or standards in jurisdictional contexts. See Jonathan Remy Nash, On the Efficient Deployment of Rules and Standards to Define Federal Jurisdiction, 65 VAND. L. REV. 509, 514-17 (2012). See generally Scott Dodson \& Elizabeth McCuskey, Structuring Jurisdictional Rules and Standards, 65 VAND. L. REV. EN BANC 31 (2012), http://www.vanderbiltlawreview.org/2012/06/structuring-jurisdictional-rules-and-standards/; Scott Dodson, The Complexity of Jurisdictional Clarity, 97 VA. L. REV. 1 (2011); Richard D. Freer, Of Rules and Standards: Reconciling Statutory Limitations on "Arising Under" Jurisdiction, 82 IND. L.J. 309 (2007); Elizabeth Y. McCuskey, Clarity and Clarification: Grable Federal Questions in the Eyes of Their Beholders, 91 NEB. L. REV. 387 (2012); Lumen N. Mulligan, Clear Rules-Not Necessarily Simple or Accessible Ones, 97 VA. L. REV. IN BRIEF 13 (2011), http://www.virginialawreview.org/inbrief.php?s=inbrief\&p=2011/ 05/02/mulligan; John F. Preis, Jurisdiction and Discretion in Hybrid Law Cases, 75 U. CIN. L. REV. 145 (2006). Michael E. Solimine and Christine Oliver Hines briefly discussed the rules and standards literature in classifying various exceptions to the final judgment rule as either rules or standards. See Solimine \& Hines, supra note 4, at 1571-72. 
doctrine. As I explain in Part IV, courts currently treat the collateral order exception as a strict rule for defining categories of orders that can be immediately appealed. As such, the current collateral order exception inhibits experimentation. But relaxing the exception to make it more standard-like could change that. Rather than a defined set of strict requirements, a more standardlike collateral order exception could permit appeals from particular types of orders when the benefit of doing so generally outweighs the costs.

This standard-like approach would leave room for the courts of appeals to adopt different approaches to particular types of orders. When asked whether a new type of order is immediately appealable, the courts of appeals will likely need to make their own assumptions about the costs and benefits of permitting collateral appeals, and reasonable people can disagree when making those assumptions. Some circuits might decide that a particular type of order is immediately appealable while others hold that it is not. As the circuits apply their different approaches, they would be able to monitor the effects of their different rules, such as the increase in appeals, the number of errors corrected, and the delay in trial court proceedings. ${ }^{11}$ Were the evidence to undermine the assumptions underlying a circuit court's initial decision or otherwise draw that initial decision into question, the court could choose to revisit it. And should the Supreme Court need to resolve a persistent split between the circuits, it could choose to base its decision, at least in part, on the evidence generated rather than its own assumptions or conjecture.

This Article thus offers a means of using judicial experimentation to generate evidence about the actual consequences of different interlocutory appeal rules. Such an approach could provide some of the empirical grounding that current reform discussions lack. This Article also explores the experimentation value of standards in a hierarchical judiciary with multiple lower courts, showing that the use of such a standard might be a good means of ultimately crafting clear rules. In other words, even in a context like jurisdiction where clear rules are highly valued, a little fuzziness might be the best way to ultimately attain that ideal. This point, though counterintuitive, suggests that standards and experimentation could play an important role in some procedural and jurisdictional contexts. I briefly address this issue at the end of Part IV.

11 These effects, though often involving the district court judge, are primarily felt by, and affect the ultimate behavior of, litigants. But changes in the availability of appeal would likely have some effect on district court decision making as well. If, for example, appellate review became relatively more likely, district courts might be more careful in-and thus spend more time on-making their interlocutory decisions. This increased time and effort would be a cost of increasing the availability of appeals. Increased availability of appellate review might also reduce the instances in which district court judges try to encourage settlement through a normally unreviewable interlocutory order. In short, changes in the availability of appeal would likely have some effect on district judge behavior and the relationship between the district court and appellate court. Those issues, while certainly interesting and a potential subject of future research, are beyond the scope of this Article. 


\section{REFORM AND CONSEQUENCES IN INTERLOCUTORY APPEALS}

This Part begins with a brief review of the law on interlocutory appeals and the debate over how best to reform it. I then demonstrate that the debate is largely (though not entirely) over consequences; arguments for and against a particular reform often concern the observable, real-world effects of that reform. But these arguments often lack empirical support and thus take place at an unhelpfully abstract level.

\section{A. The Final Judgment Rule and Its Exceptions}

District judges regularly decide a number of issues during the course of litigation. Many of these decisions are "interlocutory"-they do not resolve the entire dispute. ${ }^{12}$ Federal litigants unhappy with an interlocutory decision would often like immediate review by an appellate court. But they often can't have it. As a general matter, the federal courts of appeals have jurisdiction over only "final decisions" by a district court. ${ }^{13}$ Most federal litigants thus have to wait until the end of proceedings in the district court-when all issues have been decided and only execution of the judgment remains - before they can appeal. ${ }^{14}$

This limit on appellate jurisdiction-codified at 28 U.S.C. $\S 1291$ and commonly called the "final judgment rule"-is thought to strike the general balance between the conflicting interests in appellate review-efficiency and error correction..$^{15}$ The efficiency benefits are obvious: district court proceedings are free from appellate interruption, ${ }^{16}$ appellate judges generally address a case only once, ${ }^{17}$ litigants are saved the cost and potential harassment of multiple appeals, ${ }^{18}$ and interlocutory appeals that might eventually become unnecessary—say, because the aggrieved party ultimately prevails at trial-are avoided. ${ }^{19}$ But the final judgment rule also has costs; appellate decisions can develop unclear areas of the law and correct errors. And the delay between an erroneous district court decision and vindication on appeal can cause

12 This would include, for example, the denial of a motion to dismiss or for summary judgment, or rulings on discovery and evidentiary matters; the decision is made and the case continues in the district court.

1328 U.S.C. $\$ 1291$ (2006).

14 See Catlin v. United States, 324 U.S. 229, 233 (1945).

15 See Richard A. POSNER, ECONOMIC ANALYSIS OF LAW 805 (8th ed. 2010).

${ }^{16}$ On a more abstract level, the final judgment rule increases the independence and authority of district judges. It allows district judges to manage trial proceedings without the interference of an appellate court peering over their shoulders. See Stringfellow v. Concerned Neighbors in Action, 480 U.S. 370, 380 (1987).

${ }^{17}$ This not only reduces the general appellate case load, but also allows the appellate courts to consolidate all issues in a particular case in one appeal. Appellate judges thus need only become familiar with the record once, and their decisions can benefit from seeing these issues in the big picture that comes with a final judgment.

${ }^{18}$ See Will v. Hallock, 546 U.S. 345, 350 (2006); Stringfellow, 480 U.S. at 380.

${ }^{19}$ See Stringfellow, 480 U.S. at 380. 
substantial, sometimes irreparable, harms. ${ }^{20}$ By generally postponing appeal until the end of district court proceedings, the final judgment rule reflects a belief that in most cases the benefits of delaying appeal outweigh the costs. ${ }^{21}$

Like any rule, however, the final judgment rule only generally strikes that balance. Sometimes the balance shifts because the need of immediate review outweighs (or is at least thought to outweigh) the loss in efficiency. ${ }^{22}$ So the final judgment rule has exceptions. In fact, it has many exceptions. ${ }^{23}$ Some appear in statutes, ${ }^{24}$ others in rules of procedure, ${ }^{25}$ and still others in judicial decisions. $^{26}$

${ }^{20}$ For example, parties who cannot obtain immediate review might feel compelled to settle a dispute-even if they would have won on appeal-rather than bear the costs of discovery and trial.

${ }^{21}$ See 15A Charles Alan Wright, Arthur R. Miller \& EdWARD H. CoOper, Federal Practice and Procedure $\S 3911.2$, at 379 (2d ed. 1992) ("The final judgment rule... rests on a rough calculation that ordinarily the balance between the values of immediate appeal and delayed appeal swings in favor of deferring appeal.").

22 See Pollis, supra note 4, at 1647.

${ }^{23}$ For more in-depth overviews of exceptions to the final judgment rule, see, for example, Glynn, supra note 4, at 182-201; Martineau, supra note 4, at 729-47; Steinman, supra note 3, at 1244-72.

${ }^{24}$ See, e.g., 9 U.S.C. $\$ 16(\mathrm{a})(1)-(2)(2006)$ (permitting appeals from interlocutory orders involving arbitration); 28 U.S.C. $\$ 1292(a)(1)$ (2006) (granting appellate jurisdiction over appeals from "[i]nterlocutory orders ... granting, continuing, modifying, refusing or dissolving injunctions, or refusing to dissolve or modify injunctions"); id. §1292(a)(2) (granting appellate jurisdiction over appeals from "[i]nterlocutory orders appointing receivers, or refusing orders to wind up receiverships or to take steps to accomplish the purposes thereof'); id. $\S 1292(\mathrm{a})(3)$ (granting appellate jurisdiction over appeals from "[i]nterlocutory decrees of such district courts or the judges thereof determining the rights and liabilities of the parties to admiraity cases in which appeals from final decrees are allowed"); id. § 1292(b) (permitting appeals from orders that both the district court and court of appeals certify "involve[] a controlling question of law as to which there is substantial ground for difference of opinion and that an immediate appeal from the order may materially advance the ultimate termination of the litigation"); id. $\$ 1651$ (authorizing writs).

${ }^{25}$ See FED. R. CIV. P. 23(f) (permitting interlocutory appeals from orders granting or denying class certification); FED. R. CrV. P. 54(b) (authorizing a district court to enter a final judgment for some (but not all) of the claims or parties in such a case "if the court expressly determines that there is no just reason for delay").

${ }^{26}$ See Cohen v. Beneficial Indus. Loan Corp., 337 U.S. 541, 545- 47 (1949); Perlman v. United States, 247 U.S. 7, 12-13 (1918). On whether Cohen created an "exception" to the final judgment rule, see infra note 118. One additional judicial exception might be "pragmatic finality" under Gillespie v. United States Steel Corp., 379 U.S. 148 (1964). See generally Redish, supra note 4. The Supreme Court appears to have limited Gillespie to its unique facts: the district court's order (which had struck some but not all of a plaintiff's claims) had "disposed of an unsettled issue of national significance ... and the arguable finality issue had not been presented to [the] Court until argument on the merits." Coopers \& Lybrand v. Livesay, 437 U.S. 463, 477 n.30 (1978). 
By nearly all accounts, this system is broken and in need of repair. ${ }^{27}$ Most commentators see at least three problems.

First, the current system is too complex. ${ }^{28}$ Not only do a wealth of exceptions exist, but they also apply in different contexts, ${ }^{29}$ have different requirements, ${ }^{30}$ and are scattered throughout the U.S. Code, Federal Rules of Civil Procedure, and case law. ${ }^{31}$

Second, judges do not make sufficient use of the existing exceptions. Commentators often levy this criticism at 28 U.S.C. $\$ 1292(\mathrm{~b})$, which allows district courts to certify an order for immediate appeal. ${ }^{32}$ The decision to certify

${ }^{27}$ See, e.g., Martineau, supra note 4, at 729 ("[T] he unanimous view of commentators is that the rule has either too many or too few exceptions, but in any event requires revision."). Some suggest that the system is functioning relatively well. See, e.g., Glynn, supra note 4, at 179 ("[T]he current regime is in far better shape than commonly appreciated."); Steinman, supra note 3, at 1272 ("The federal courts . . have worked within the cumbersome doctrinal and procedural framework to implement a system of interlocutory appellate review that, in practice, is fairly sensible. If one looks at the results on the ground-i.e., which interlocutory orders are immediately appealable and which are not-the jurisdictional landscape is commendable."). But they, too, note that there is still room for reform. See Glynn, supra note 4, at 181; Steinman, supra note 3, at 1277.

${ }^{28}$ See Carrington, supra note 4, at 165-66 (noting "the unconscionable intricacy of the existing law, depending as it does on overlapping exceptions, each less lucid than the next"); Cooper, supra note 4, at 157 ("The final judgment requirement has been supplemented by a list of elaborations, expansions, evasions, and outright exceptions that is dazzling in its complexity."); Eisenberg \& Morrison, supra note 4, at 291 (calling the current system "arcane and confusing"); Pollis, supra note 4, at 1651 (noting the "labrynthian conglomeration of jurisdictional rules"); Maurice Rosenberg, Solving the Federal FinalityAppealability Problem, L. \& CONTEMP. PROBS., Spring 1984, at 171, 172 ("The existing federal finality-appealability situation is an unacceptable morass."); Waters, supra note 4, at 556 (noting the "dizzying array of statutory and judicially-created [finality] exceptions").

${ }^{29}$ Some exceptions to the final judgment rule, such as extraordinary writs, are available in most or nearly all cases. See 28 U.S.C. $\$ 1651$ (2006). Others apply relatively broadly, such as appeals regarding injunctive relief and certified appeals. See id. §1292(a)(1) (available whenever injunctive relief is sought); $i d$. $\S 1292$ (b) (available in any civil case). Others are much narrower. See 9 U.S.C. $\S 16($ a) (2006) (applies only in cases involving arbitration).

${ }^{30}$ Some exceptions to the final judgment rule are essentially appeals as of right-they apply so long as the order is of the necessary type. See, e.g., 9 U.S.C. $§ 16$ (a) (2006) (orders denying arbitration). Others have substantive requirements, such as those for a certified appeal or a writ of mandamus. See 28 U.S.C. $\$ 1292$ (b) (2006) (requiring that the district court order "involve[] a controlling question of law as to which there is substantial ground for difference of opinion"); id. $\S 1651$ (2006) (requiring that the district court patently err and leave a party with no other effective remedy, see, e.g., Cheney v. U.S. Dist. Court, 542 U.S. $367,380-82$ (2004)). And still others contain a discretionary element, such that the availability of appeal depends at least in part on a court's exercise of discretion; certified appeals are again an example, as are discretionary appeals of orders regarding class certification. See id. § 1292(b) (2006); FED. R. CIV. P. 23(f).

${ }^{31}$ See supra notes $24-26$.

3228 U.S.C. $\$ 1292$ (b) (2006) (authorizing district court judges to certify for an immediate appeal an order that "involves a controlling question of law as to which there is 
an order under $\S 1292$ (b) is discretionary, and the courts of appeals can refuse to hear a certified appeal for any reason. ${ }^{33}$ Most commentators contend that judges underuse $\S 1292$ (b), such that it "has not been an effective method for obtaining appellate review over interlocutory orders." 34

Third (and perhaps most importantly), the current system of interlocutory appeals is not sufficiently predictable. To be sure, some of the exceptions are themselves uncontroversial; they are relatively simple and predictable, and they strike a reasonable balance between the needs of efficiency and error correction. But these predictable exceptions are also quite narrow. They apply only in specific and sometimes rare situations, such as orders refusing to compel arbitration and orders granting or denying class certification. ${ }^{35}$

The broader exceptions are much less predictable. They are plagued by vague terms and inconsistent treatment in the courts, such that both litigants and judges spend far too much time trying to determine what can be appealed and when. ${ }^{36}$ The collateral order doctrine best illustrates this problem of predictability. The doctrine (as discussed in greater depth below) consists of a three-part test for determining whether a district court order can be immediately appealed. The order must:

(1) "conclusively determine the disputed question,"

(2) "resolve an important issue completely separate from the merits of the action, and"

(3) "be effectively unreviewable on appeal from a final judgment." 37

The collateral order doctrine is both the most common and most maligned exception to the final judgment rule; commentators bemoan its vague terms, unpredictable application, and inconsistent treatment in the Supreme Court. ${ }^{38}$

substantial ground for difference of opinion" when "an immediate appeal from the order may materially advance the ultimate termination of the litigation").

${ }^{33}$ See id. ("The Court of Appeals which would have jurisdiction of an appeal of such action may thereupon, in its discretion, permit an appeal to be taken from such order . ...").

34 Steinman, supra note 3 , at 1245.

${ }^{35}$ See 9 U.S.C. $\S 16(\mathrm{a})(1)(\mathrm{B})$ (2006) (permitting appeals from "the den[ial of] a petition ... to order arbitration to proceed"); FED. R. CIV. P. 23(f). Another example is the exception for district court orders disposing of some (but not all) of the claims or parties in a multi-party or multi-claim case. See FED. R. CIV. P. 54(b).

${ }^{36}$ See Cooper, supra note 4, at 157 (arguing that even "[l] awyers and judges who are expert in working with the system ... often encounter elusive uncertainty in seeking clear answers to many problems"); Luther T. Munford, Dangers, Toils, and Snares: Appeals Before Final Judgment, LITIG., Spring 1989, at 18, 18 (noting that the appealability regime "provides the kind of excursions into legal history and abstract analysis that can drive practical litigators crazy"); Rosenberg, supra note 28, at 172 ("Entirely too much of the appellate courts' energy is absorbed in deciding whether they are entitled under the finality principle and its exceptions to hear cases brought before them-and explaining why or why not.").

${ }^{37}$ Coopers \& Lybrand v. Livesay, 437 U.S. 463, 468 (1978) (numbering added). 


\section{B. Reform and Consequences}

Given these criticisms, the literature on interlocutory appeals often calls for reform. ${ }^{39}$ And proposed reforms generally fall into one of two camps. ${ }^{40}$ One proposes a system of largely categorical rules listing the types of orders that can be appealed before final judgment. ${ }^{41}$ Under such a regime, rulemakers would determine what classes of orders merit immediate appeal. ${ }^{42}$ The other camp of reformers advocates a system of largely discretionary jurisdiction over interlocutory orders. This approach would limit or eliminate many of the current exceptions to the final judgment rule, replacing them with the courts of appeals' discretion to grant or deny interlocutory appeals. ${ }^{43}$

The disagreement between these two camps largely concerns the likely effects of the proposed reforms. Commentators on both sides of the debate agree generally on the relevant values and considerations: they all want a system that permits immediate appeals when the benefits outweigh the costs,

${ }^{38}$ See, e.g., 15A WRIGHT, MILLER \& COOPER, supra note 21, § 3911, at 330 (noting the several Supreme Court decisions that "alternately support and twist or ignore the pronounced elements of the [collateral order] doctrine"); Anderson, supra note 4, at 540 (arguing that the collateral order doctrine is built on "inconsistent [Supreme Court] opinions" that "caus[e] unacceptable confusion over iwhich nonfinal rulings are appealable"); Gerdy, supra note 4, at 246, 248 (characterizing a recent collateral order decision as "less than consistent and even contradictory of earlier iterations of the doctrine" and criticizing it for threatening to expand the collateral order doctrine "beyond reason"); Glynn, supra note 4, at 205; Steinman, supra note 3, at 1277 (characterizing the collateral order doctrine as "confus[ed] and incoheren[t]").

${ }^{39}$ See, e.g., Glynn, supra note 4, at 258-67; Steinman, supra note 3, at 1276-94.

${ }^{40}$ For a more in-depth review of the literature, see Martineau, supra note 4, at 749-70. A third, smaller camp of reformers advocate for the elimination of appeals as of right, replacing it with an entirely discretionary system. See, e.g., Crick, supra note 4, at 564; Robert M. Parker \& Ron Chapman, Jr., Accepting Reality: The Time for Adopting Discretionary Review in the Courts of Appeals Has Arrived, 50 S.M.U. L. REv. 573, 579-82 (1997). And a portion of the literature focuses on the appealability of specific types of district court decisions via either an existing or new avenue of interlocutory appeal. See generally Feldman, supra note 4 (addressing the appealability of district court orders denying the appointment of counsel); Pollis, supra note 4 (addressing the appealability of district court orders in multi-district litigation); Robertson, supra note 4 (addressing the appealability of discovery orders implicating claims of privilege); Waters, supra note 4 (addressing the appealability of district court orders in mass-tort cases).

${ }^{41}$ See Carrington, supra note 4, at 167-68; Glynn, supra note 4, at 259; Rosenberg, supra note 28 , at 179.

42 Timothy P. Glynn has argued for clear rules that permit an immediate appeal in specific categories of "problem areas." See Glynn, supra note 4, at 259 ("Expansion of interlocutory appellate review should be limited primarily to mandatory review of narrowly defined categories of orders within 'problem areas."'). Glynn does not, however, suggest any particular "problem areas" for which categorical rules should be drawn. See id. at 261-62.

${ }^{43}$ See Cooper, supra note 4, at 163-64; Eisenberg \& Morrison, supra note 4, at 293302; Martineau, supra note 4, at 748-87; Nagel, supra note 4, at 214-22; see also Redish, supra note 4 , at $124-27$. 
and they agree that striking this balance requires attention to the effects or consequences of the proposed reforms. ${ }^{44}$ The literature thus evaluates potential reforms by asking whether they would, for example, result in too many interlocutory appeals, correct enough district court errors that are in need of immediate correction, unduly delay trial court proceedings, or result in parties using interlocutory appeals to harass the other side..$^{45}$

As in many legal debates, advocates of both categorical rules and discretion claim that their proposed reform will have the better consequences. ${ }^{46}$ And these claims often focus largely on the effects of their reforms. This "empirical" component of the debate addresses the observable changes in the world-for example, the actual number of additional appeals or the actual delay in trial court proceedings. To be sure, these claims also have an evaluative component that requires a value judgment-for example, whether the number of additional appeals is "too many" or whether the delay in trial court proceedings is "undue." But "empirical" claims dominate the discussion, such that the debate over interlocutory appeals could largely be influenced by empirical evidence.

Few writing in this area rely on such evidence. They instead rely on assumptions about litigant and judicial behavior when predicting the effects of possible reforms. The debate about consequences and effects thus takes place at an abstract level, driven by logic and reason rather than evidence and experience.

Consider, for example, the argument about appellate workloads. By nearly all accounts, the federal appellate courts have too many cases, and reform efforts are thus sensitive to potentially increasing appellate caseloads. Those arguing for discretionary review contend that their reform will not increase caseloads and might actually decrease them. Howard B. Eisenberg and Alan B. Morrison assert a switch to discretion will result in only a "short term" increase in workload, as courts will have to begin deciding petitions for review as well as more cases on the merits. ${ }^{47}$ But "[i]n the long term," they argue, "as the courts become accustomed to working with the new rule, any increase will be more than offset by decreases in appeals from final judgments." 48 Eisenberg and Morrison also predict that the number of petitions for appeal. will not be overwhelming because "[l]itigants and their counsel will recognize that the

44 This is not to say that the debate can be entirely resolved through empirics; conclusions that there are too many appeals or that an issue is too important to delay review, for example, require value judgments. Still, much of the disagreement concerns the observable effects of various reforms.

45 See, e.g., Anderson, supra note 4, at 542; Eisenberg \& Morrison, supra note 4, at 294-95; Solimine, supra note 4, at 1189-91.

${ }^{46}$ See Michael C. Dorf, Foreword: The Limits of Socratic Deliberation, 112 HaRv. L. REV. 4, 53 (1998) ("[T]he adjudicatory domain in which consequences matter is substantial.").

${ }^{47}$ Eisenberg \& Morrison, supra note 4, at 301.

${ }^{48} \mathrm{Id}$; see also id. at 302 ("[T]o the extent that there is any increased burden on the courts of appeals, it should be offset by a decrease in time spent deciding difficult jurisdictional issues ...."). 
process is designed for the exceptional case and that seeking interlocutory review over routine rulings will generally not be a way to improve relations with the trial judge who is still handling the case." 49 And the time for reviewing petitions to appeal, Eisenberg and Morrison argue, would be minimal; "judges (without the need for law clerk input in most cases) should be able to read the papers quite quickly and make an informed judgment about whether the case warrants an exception to the final judgment rule." 50

Timothy P. Glynn disagrees. He contends that discretionary review would instead increase the courts of appeals' workload, and he attributes this increase to "the possibility of multiple appeals" in a single case and interlocutory appeals from cases that would have otherwise never been appealed due to issues becoming moot or the case ultimately settling. ${ }^{51}$ And according to Glynn, if the courts of appeals want to hear immediate appeals when necessary to avoid irreparable harm, they will have to spend significant time with appeal petitions. "Many errors are subtle," he notes, "involving the inappropriate extension of a legal principle or a misapplication of the law.... Careful review may [therefore] be necessary to determine whether there is probable error."52

Related to workload arguments are those about "collateral litigation" over whether a particular order is immediately appealable. Glynn recognizes that categorical rules "will produce some collateral litigation on the issue of appealability," but he suggests that "a carefully worded category-based rule is unlikely to spawn the quantum of collateral litigation that judicially crafted interpretive doctrines or exceptions governed by broadly defined standards have generated in the past." 53 Advocates of discretion disagree. ${ }^{54}$ Categorical rules, they argue, are likely to spawn collateral litigation just like their judicially crafted counterparts. ${ }^{55}$ Robert J. Martineau states this position plainly: categorical rules "will not decrease, and will almost inevitably increase, litigation over what is appealable of right." 56

So who's right? Who knows? Eisenberg and Morrison, Glynn, and Martineau all present plausible arguments; a switch to discretionary review might produce more work for the courts of appeals, or it might produce less. Even if the direction of the change were clear (say, that appeals would increase), the magnitude wouldn't. And without first knowing this effect, it is difficult to make the evaluative judgment of whether that increase would be "too much."

The argument over whether rulemaking would be sufficiently flexible also demonstrates the abstract nature of debates over interlocutory appeal reform;

${ }^{49} I d$. at 302 .

${ }^{50} \mathrm{Id}$.

51 Glynn, supra note 4, at 238.

52 Id. at $238-39$.

${ }^{53} \mathrm{Id}$. at $260 \mathrm{n} .301$.

54 See Martineau, supra note 4, at 773-74, 786; Nagel, supra note 4, at 220.

55 See Martineau, supra note 4, at 773-74; Nagel, supra note 4, at 220.

${ }^{56}$ See Martineau, supra note 4 , at 786. 
both sides present plausible-yet-conflicting arguments about the flexibility of rulemaking and offer no way for determining who is right. Rulemaking, advocates of rules argue, could both reflect current experience and adapt through amendment or revision to changing circumstances. ${ }^{57}$ Rulemakers could add or subtract categories from the list of immediately appealable orders as experience warrants; "[f]or example, at some point, an area of the law may cease to be a problem area-or become less of a problem than other areas-and interlocutory review can be abandoned." 58 And rulemakers could "feel free to remove a category if it creates an unanticipated burden for the circuit courts or unforeseen hardships for litigants or district courts." 59

Advocates of discretion doubt these claims of flexibility. Appellate jurisdiction, they argue, is inherently complex with its conflicting values of efficiency and error correction, and no ex ante rule or rules could accommodate this complexity ${ }^{60}$ Martineau has suggested "that it is virtually impossible to identify in advance classes or types of interlocutory orders that should be appealable immediately." 61 Whether an order "should be appealable immediately will vary from period to period and from case to case," he argues, such that "attempting to classify interlocutory orders for appeal purposes whether by statute, rule, or judicial decision, can be nothing other than an exercise in futility." 62

Similarly abstract disagreements over the effect of potential reforms abound in the literature. Discretion, we are told, would better develop areas of the law most in need of clarification through interlocutory review. ${ }^{63}$ Or it wouldn't. ${ }^{64}$ Rules will provide clear notice as to what can be appealed. ${ }^{65}$ Or they won't ${ }^{66} \mathrm{~A}$ categorical approach would produce a never-ending list of exceptions to the

${ }^{57}$ See Glynn, supra note 4 , at 261 (contending that a categorical approach to interlocutory appeals "offers potential flexibility"); Rosenberg, supra note 28, at 179 (suggesting that "experience with [the] stubborn problem [of determining appealability] can be converted into rule-prescribed standards").

${ }^{58}$ Glynn, supra note 4 , at 261 .

${ }^{59} \mathrm{Id}$.

${ }^{60}$ See Cooper, supra note 4, at 157; Martineau, supra note 4, at 775 ; Nagel, supra note 4 , at 216.

${ }^{61}$ Martineau, supra note 4, at 775.

$62 \mathrm{Id}$.

${ }^{63}$ See Eisenberg \& Morrison, supra note 4, at 291 (noting that the current appellate regime "denies review to many 'non-final' orders ... whose resolution would aid in the development of the law").

${ }^{64}$ See Glynn, supra note 4, at 250 ("Discretionary review ... will produce neither the amount nor the type of appellate review needed to clarify the law in areas that historically have evaded review.").

${ }^{65}$ Rosenberg, supra note 28 , at 179 (suggesting that rules "will give both the courts and the bar a basis for knowing which interlocutory orders are immediately appealable").

${ }^{66}$ The arguments against the clarity of rules are essentially those suggesting that they will produce collateral litigation; truly "clear" rules wouldn't require substantial litigation over their scope. See supra notes 53-56 and accompanying text. 
final judgment rule. ${ }^{67}$ Or it wouldn't. ${ }^{68}$ Some say that categorical rules "offer[] the most efficient and reliable way to reduce the number of errors in interlocutory orders that inflict severe irreparable harm and to enhance development of the law." 69 Others say that "[t]he only proposal that both serves the purposes of the final judgment rule and gives the necessary flexibility to permit an immediate appeal of an interlocutory order in appropriate cases" is a system of discretion. ${ }^{70}$

All of these arguments contain plausible positions on the effects of particular reforms. And therein lies the problem. The literature contains two inconsistent views of how best to reform interlocutory appeals, each supported by plausible-yet-conflicting claims about the consequences of those reforms. Lacking evidence as to the actual consequences of any proposed reform, there is no way to evaluate such arguments other than to agree or disagree with the logic and normative commitments at their core.

To be sure, not everyone speaks solely in logic or normative commitments. ${ }^{71}$ Yet even with these exceptions, the debate over interlocutory appeals remains abstract and at an impasse.

\section{JUDICIAL EXPERIMENTATION AND STANDARDS}

Despite the lack of empirical support, both sides of the debate over interlocutory appeal reform take a largely consequentialist approach. This kind of approach to decisionmaking, perhaps best captured in modern legal pragmatism, emphasizes a "heightened ... concern for consequences and thus a disposition to base policy judgments on them rather than on conceptualisms and

67 See Martineau, supra note 4, at 774.

${ }^{68}$ See Glynn, supra note 4, at 261 ("The list [of immediately appealable orders] should never be long, and categories should be limited to true problem areas ....").

${ }^{69} \mathrm{Id}$. at 260 .

${ }^{70}$ Martineau, supra note 4, at 788 .

${ }^{71}$ Edward H. Cooper, for example, once emphasized that "the relationships between trial courts and appellate courts must be rested on the lessons of experience," not "a process of logical reasoning from unshakable premises about the nature of the appellate process." Cooper, supra note 4 , at 158 . A few discretion advocates have also tried to rely on Wisconsin's experience with discretionary appeals. Wisconsin adopted a system of discretionary appeals in 1978, see WIS. STAT. ANN. $§ 808.03(2)$ (West 1994), and discretion has apparently worked well in Wisconsin; appellate workloads have been manageable, the potential flood of frivolous appeals never materialized, and trial court proceedings have not been exceedingly delayed. See Eisenberg \& Morrison, supra note 4, at 297-301; Martineau, supra note 4, at 777-87. This demonstrates, discretion advocates have argued, that many of the concerns about discretion in the federal system are overblown. See Martineau, supra note 4, at 777. Rule advocates have responded, however, that unique characteristics of federal litigation (greater complexity, well-resourced parties) render the Wisconsin experience largely unhelpful in predicting the possible federal experience. See Glynn, supra note 4, at 236-37. 
generalities." 72 But the debate also illustrates one of the major problems of consequence-focused approaches: even if lawmakers agree that consequences should guide legal reform, and even if they can agree on what the best consequences would be, it can be difficult to determine which reform would produce the best consequences.

Experimentation offers one solution to this issue, as it often produces at least some evidence about the effects of an approach to a particular legal problem. In this Part, I first explain why an experimental approach would be appropriate in the context of interlocutory appeals. I then present one general means of facilitating judicial experimentation, specifically, the use of a standard in a hierarchical judicial system.

\section{A. Judicial Experimentation in Interlocutory Appeals}

Many know Justice Brandeis's statement that "one of the happy incidents of the federal system [is] that a single courageous State may, if its citizens choose, serve as a laboratory; and try novel social and economic experiments without risk to the rest of the country." 73 Yet experimentation need not be a solely legislative phenomenon; judges can also experiment. ${ }^{74}$ And such experimentation can take various forms. Legislatures can encourage it, as illustrated by Andrew S. Gold's recent call for legislation permitting courts to experiment with methods for selecting the lead plaintiff in securities class actions. ${ }^{75}$

Judges can also initiate and conduct their own experiments, and "percolation" theory is perhaps the most popular justification for such judgedriven experimentation. ${ }^{76}$ Under this theory, Supreme Court justices should

72 Richard A. Posner, How Judges Think 238 (2008). "Consequences" in this sense is a broad term, encompassing "systemic, including institutional, consequences as well as consequences of the decision in the case at hand." Id.

${ }^{73}$ New State Ice Co. v. Liebmann, 285 U.S. 262, 311 (1932) (Brandeis, J., dissenting).

${ }^{74} \mathrm{By}$ judicial experimentation, I do not merely mean a court trying out a new approach to a legal problem; innovation alone does not constitute experimentation. Experimentation as I mean it requires an attention to the consequences of a legal approach. Experimentation thus primarily occurs when a court or (more often) multiple courts try different approaches to a single legal problem, thereby allowing a comparison of those approaches' consequences. Conceivably, however, experimentation could occur when a court tries only one approachit could find that the one approach has the consequences it hoped for and accordingly stick with it, not trying anything else.

${ }^{75}$ Andrew S. Gold, Experimenting with the Lead Plaintiff Selection Process in Securities Class Actions: A Suggestion for PSLRA Reform, 57 DePAUL L. REV. 447, 467-68 (2008).

${ }^{76}$ For helpful discussions of percolation, see Thomas E. Baker, Siskel and Ebert at the Supreme Court, 87 MiCH. L. REV. 1472, 1482-87 (1989) (reviewing SAMUEL ESTREICHER \& John SEXton, Redefining the SuPreme CourT'S Role: A Theory of MaNaging THE Federal Judicial Process (1986)); Thomas E. Baker \& Douglas D. McFarland, The Need for a New National Court, 100 HARV. L. REV. 1400, 1407-09 (1987); Paul M. Bator, What Is Wrong with the Supreme Court?, 51 U. PITT. L. REv. 673, 689-91 (1990); Evan H. 
allow several different courts of appeals to decide a legal issue-to let it "percolate" in the lower courts-before stepping in to resolve it.

Views vary on percolation's exact benefit. Some suggest it improves the Supreme Court's reasoning - the lower courts offer several ways to, for example, interpret a piece of statutory text, and the Supreme Court can pick the "best" interpretation. 77 Others emphasize percolation's ability to generate evidence about the actual consequences of different approaches to a single legal issue. ${ }^{78}$ Michael C. Dorf, for example, has suggested that Supreme Court decisionmaking could benefit from consequence-focused percolation. ${ }^{79}$ Dorf argued that the Court should "[e]xplicitly pay[] greater attention to the likely consequences of its decisions" 80 but recognized that the Court often lacks the means of learning those consequences. ${ }^{81}$ One solution Dorf offered was delaying review of circuit splits. "[T]emporary disuniformity of federal law can assist the Court in learning from experience," Dorf argued, because "a circuit split creates a record of the consequences of different legal regimes." 82

Regardless of whether percolation is supposed to improve reason or illustrate consequences, it has been the subject of several sharp criticisms. ${ }^{83}$

Caminker, Precedent and Prediction: The Forward-Looking Aspects of Inferior Court Decisionmaking, 73 TEX. L. REV. 1, 54-60 (1994); Dorf, supra note 46, at 60-69; Samuel Estreicher \& John E. Sexton, A Managerial Theory of the Supreme Court's Responsibilities: An Empirical Study, 59 N.Y.U. L. REV. 681, 715-28 (1984); Doni Gewirtzman, Lower Court Constitutionalism: Circuit Court Discretion in a Complex Adaptive System, 61 AM. U. L. REV. 457, 481-95 (2012); Walter V. Schaefer, Reducing Circuit Conflicts, 69 A.B.A. J. 452 , 454-55 (1983); J. Clifford Wallace, The Nature and Extent of Intercircuit Conflicts: $A$ Solution Needed for a Mountain or a Molehill?, 71 CALIF. L. REV. 913, 928-32 (1983). See generally Todd J. Tiberi, Comment, Supreme Court Denials of Certiorari in Conflicts Cases: Percolation or Procrastination?, 54 U. PITT. L. REV. 861, 861 (1993).

${ }^{77}$ See Caminker, supra note 76, at 56 (noting the suggestion that lower courts can "independently interpret existing precedents, identify and flesh out various legal principles and their applications, and construct what they consider to be optimal and workable doctrinal rules"; the Supreme Court can then rely on those analyses); Patricia M. Wald, Upstairs/Downstairs at the Supreme Court: Implications of the 1991 Term for the Constitutional Work of the Lower Courts, 61 U. CIN. L. REV. 771, 790 (1993) ("Percolation allows the High Court to take advantage of a wide spectrum of reasoning and analysis on the subject as well as a variety of factual settings in which the issue may have arisen."); Wallace, supra note 76, at 930 (discussing percolation's "potential for improving the quality of federal justice by encouraging more reasoned and principled decisions on issues of federal law").

${ }^{78}$ Caminker, supra note 76, at 59; see, e.g., Charles L. Black, Jr., The National Court of Appeals: An Unwise Proposal, 83 Y ALE L.J. 883, 898 (1974).

${ }^{79}$ Dorf, supra note 46 , at 65.

${ }^{80} \mathrm{Id}$. at 8 .

${ }^{81} \mathrm{Id}$. at 51.

$82 \mathrm{Id}$. at 65.

${ }^{83}$ See Baker, supra note 76, at 1482-87; Baker \& McFarland, supra note 76, at 1408 09; Bator, supra note 76, at 689-91; Daniel J. Meador, A Challenge to Judicial Architecture: Modifying the Regional Design of the U.S. Courts of Appeals, 56 U. CHI. L. REV. 603, 634 (1989) ("As applied to judicial interpretations of federal statutes, 'percolation' is a 
Both judges and academic commentators question whether percolation's theoretical benefits actually materialize, as it is unclear whether the process percolation theory envisions actually occurs. Some question whether Supreme Court Justices care about or even read lower court opinions. ${ }^{84}$ So if percolation's supposed benefit stems from lower courts' reasoning, it is unclear whether that reasoning actually reaches the Supreme Court. ${ }^{85}$ And if percolation is meant to generate evidence as to the actual consequences of different approaches to a single legal issue, the Court must monitor or otherwise learn about those consequences. The Court doesn't appear to do so. ${ }^{86}$ Finally, even if the Supreme Court did try to learn from the courts of appeals' experience, some question whether that actually results in better Supreme Court decisions. ${ }^{87}$

Moreover, percolation can have significant costs. Percolation requires disuniformity in interpretations of federal law, such that similarly situated litigants will be treated differently depending on the circuit in which they litigate. This, critics argue, is inequitable, and conflicts with notions of a "national" law. 88 Critics also suggest that percolation fosters uncertainty and unnecessary litigation. ${ }^{89}$ Percolation thus imposes costs on individuals, and those costs are particularly high for those that operate in more than one circuit (like corporations). ${ }^{90}$

euphemism for incoherence."); William H. Rehnquist, The Changing Role of the Supreme Court, 14 FLA. ST. U. L. REV. 1, 11-12 (1986); Joseph F. Weis, Jr., Disconnecting the Overloaded Circuits-A Plug for a Unified Court of Appeals, 39 ST. LoUIS U. L.J. 455, 46163 (1995).

${ }^{84}$ See Henry J. Friendly, The "Law of the Circuit" and All That, 46 ST. JOHN's L. REV. 406,407 (1972) ("If a case involves questions of federal law of such importance as to be reviewed by the Supreme Court, the views of the court of appeals count, and should count, for little. I am unable to share the view, expressed on occasion by some polite Justices and entertained by some of my colleagues, that we have much to contribute in such cases; I doubt whether many of the Justices even read our opinions, at least on constitutional issues, except as these are filtered through the briefs of counsel or the memoranda of law clerks.").

85 See, e.g., Bator, supra note 76, at 690.

${ }^{86}$ See Caminker, supra note 76 , at 59 ("It is already a stretch to assume today that Justices or their clerks carefully read lower court opinions. It goes even further to assume that Justices actually monitor and compare the actual operation of divergent lower court rules, particularly when the Court's interpretive methodologies frequently eschew the relevance of such empirical data." (footnotes omitted)).

${ }^{87}$ See, e.g., Baker, supra note 76, at 1486; Tiberi, supra note 76, at 868.

${ }^{88}$ See, e.g., Baker, supra note 76, at 1487 ("Conflicts that go unresolved are hurtful to the inherent nature of a national law."); Meador, supra note 83, at 634 ("The percolation that produces intercircuit inconsistencies and incoherence may provide intellectual stimulation for academicians, but in the world of human activity it works costly inequities.").

${ }^{89}$ See, e.g., Baker \& McFarland, supra note 76, at 1407 (suggesting that under a system "in which conflict is not simply tolerated but actually encouraged, uncertainty or incoherence is inevitable"); Bator, supra note 76, at 690.

${ }^{90}$ See, e.g., Wallace, supra note 76 , at 931. 
This all being said, the general arguments for and against percolation are too acontextual to determine its merit in any particular context. ${ }^{91}$ Specifically with regard to generating evidence about the consequences of various legal approaches, percolation could work in some contexts but not in others. For some issues, courts might be able to monitor and internalize the evidence percolation generates. And the costs of disuniformity and unnecessary litigation might vary among contexts. In short, whether percolation will work and at what cost will likely depend on the context. ${ }^{92}$

In the context of interlocutory appeals, percolation could work. The courts of appeals have both the ability and incentive to monitor and use evidence about the consequences of different appealability rules since these consequences are mostly internal to the courts. If, for example, permitting interlocutory appeals over a particular type of order results in too many appeals, the courts of appeals will likely notice. The same is true for other consequences, such as the rate of district court error (and concomitant need for the review), the delay in district court proceedings, and the use of interlocutory appeals for delay or harassment. Thus, the common criticism that courts lack the means to monitor the consequences of divergent approaches is weaker in the context of interlocutory appeals.

Moreover, the percolation's costs are likely smaller in this context. To the extent that conflicting interpretations of law affect litigant behavior, a conflict over the availability of an interlocutory appeal likely has a smaller effect on primary behavior than a conflict over substantive law. If the Eighth and Tenth Circuits reach conflicting interpretations of a substantive federal law, people in Kansas City, Missouri will be subject to different law than people in Kansas City, Kansas. And this differential could, as critics of percolation note, affect pre-litigation behavior. Differential availability of an interlocutory appeal, however, is less likely to do so. To be sure, there is arguably something inequitable when a litigant in the Eighth Circuit can appeal an interlocutory order but a litigant in the Tenth Circuit cannot; the litigant in the Tenth Circuit might end up settling rather than taking the case to final judgment. But prelitigation, outside-the-courtroom effects, are probably small or even nonexistent. Accordingly, conflicts in the law of interlocutory appeals seem to have fewer costs than conflicts in other areas.

91 See Dorf, supra note 46 , at 66 ("[B]alanced against the leaming facilitated in each case by temporary disuniformity are the costs that may accompany legal uncertainty, including unprotected reliance, inability to plan, and excessive litigation. Hence, percolation will frequently not be worth the cost. This is not to say, however, that percolation would never be justified." (footnotes omitted)); see also Estreicher \& Sexton, supra note 76, at 720.

92 For a more contextual argument regarding percolation, see John $\mathrm{M}$. Golden, The Supreme Court as "Prime Percolator": A Prescription for Appellate Review of Questions in Patent Law, 56 UCLA L. REV. 657, 700-09 (2009). 
The general criticisms of judicial experimentation via percolation thus have less force in the context of interlocutory appeals. ${ }^{93}$ Indeed, judicial experimentation might be one way past the current impasse in the debate over interlocutory appeals; the debate is about consequences, but we have little information on the actual consequences of any proposed reform. Some experimentation could address this lack.

The rest of this Article advocates an approach to percolation that focuses on the use of standards in a hierarchical judicial system. The rules and standards literature has long suggested that standards are one way to generate information as to the consequences of an approach to a legal problem. But the literature has overlooked the full extent to which standards can facilitate judicial learning by focusing on a single court. Broadening the analysis to include multiple lower courts in a judicial hierarchy reveals that standards have the potential to foster experimentation in a way that should prove useful to debates over interlocutory appeals.

\section{B. Standards in Transition}

The distinction between rules and standards will be familiar to most readers ${ }^{94}$ (Frederick Schauer recently called it "tediously" so ${ }^{95}$ ). In brief, legal directives exist on a continuum of precision between rules and standards. ${ }^{96}$ The prototypical rule at one end has a definite factual trigger and a determinate outcome, ${ }^{97}$ while the prototypical standard at the other end directly invokes

93 These considerations might suggest that percolation would be appropriate in other procedural or jurisdictional contexts. That might be the case, and I briefly return to this point in Part IV.C.

94 The rules and standards literature is vast. Helpful discussions can be found in Frederick Schauer, Playing by the Rules: A Philosophical Examination Of RuleBASED DECISION-MAKING IN LAW AND IN LIFE (1991) [hereinafter SCHAUER, PLAYING BY THE RULES]; Isaac Ehrlich \& Richard A. Posner, An Economic Analysis of Legal Rulemaking, 3 J. LEGAL STUD. 257 (1974); Joseph R. Grodin, Are Rules Really Better Than Standards?, 45 HASTINGS L.J. 569 (1994); Louis Kaplow, Rules Versus Standards: An Economic Analysis, 42 DUKE L.J. 557 (1992); Duncan Kennedy, Form and Substance in Private Law Adjudication, 89 HARV. L. REV. 1685 (1976); Russell B. Korobkin, Behavioral Analysis and Legal Form: Rules vs. Standards Revisited, 79 OR. L. REV. 23 (2000); Frederick Schauer, Rules and the Rule of Law, 14 HARV. J.L. \& PUB. POL'Y 645 (1991); Pierre Schlag, Rules and Standards, 33 UCLA L. REV. 379 (1985); Kathleen M. Sullivan, The Justices of Rules and Standards, 106 HARV. L. REV. 22 (1992); Cass R. Sunstein, Problems with Rules, 83 CALIF. L. REV. 953 (1995).

${ }^{95}$ Frederick Schauer, The Tyranny of Choice and the Rulification of Standards, $14 \mathrm{~J}$. CONTEMP. LEGAL ISSUES 803, 804 (2005).

${ }^{96}$ See Larry Alexander, Incomplete Theorizing: A Review Essay of Cass Sunstein's Legal Reasoning and Political Conflict, 72 NOTRE DAME L. REV. 531, 542 (1997); Ehrlich \& Posner, supra note 94, at 258; Kaplow, supra note 94, at 561-62; Kennedy, supra note 94, at 1689; Sullivan, supra note 94, at 57.

${ }^{9}$ See SCHAUER, PLAYING BY THE RULES, supra note 94, at 23; Alexander, supra note 96, at 541; Schlag, supra note 94, at 382; Sullivan, supra note 94 , at 58. 
some underlying purpose. ${ }^{98}$ A posted speed limit of fifty-five miles per hour is a rule; an order to "drive safely" is a standard.

Rules and standards have their own virtues and vices. Rules are often more predictable, more certain, and better at constraining power than standards. ${ }^{99}$ These benefits come at the cost, however, of sometimes dictating outcomes that are inconsistent with the rule's underlying purpose. This is often described as rules' over- and underinclusion. ${ }^{100}$ Standards are thought to be the opposite, as they are flexible, adaptable, and better at attaining their underlying purpose. But they are also often unpredictable and a poor check on abuses of power. ${ }^{101}$

Given the costs and benefits of each approach, neither rules nor standards are inherently better than the other. Instead, the superiority of one over the other depends on context. ${ }^{102}$ In some contexts, the benefits of having a rule-any rule-might outweigh any substantive injustices that result from a rule's overand underinclusion. And when certainty and predictability are of particular value, rules also might be the better choice. But in contexts in which adaptability is especially important, a standard might better accommodate the relevant interests.

The choice of a rule or standard is not necessarily static or final. Rules sometimes become more standard-like, and-of particular relevance herestandards sometimes transition into rules. Such transitional standards, as the

98 See Kennedy, supra note 94, at 1688; Sullivan, supra note 94 , at 58.

${ }^{99}$ See Sunstein, supra note 94, at 974.

100 See Ehrlich \& Posner, supra note 94, at 268; Sullivan, supra note 94, at 58.

101 See Ehrlich \& Posner, supra note 94, at 258; Schlag, supra note 94, at 383; Sullivan, supra note 94, at 59; Sunstein, supra note 94, at 965 . The rules and standards literature addresses several other potential pros and cons of rules and standards that I will not discuss here. See Sullivan, supra note 94, at 63-64. See generally Kennedy, supra note 94; Seana Valentine Shiffrin, Inducing Moral Deliberation: On the Occasional Virtues of Fog, 123 HARV. L. REV. 1214 (2010). Some commentators take a more narrow, "economic" approach. See Korobkin, supra note 94, at 31 ("Analyses are economic in a narrower sense ... when they set aside deontological, rights-based arguments and political philosophy arguments about rules and standards and emphasize the incentive effects the choice of form will have on the behavior of citizens who are subject to the law and on those charged with enforcing the law." (footnotes omitted)). John Preis and Jonathan Remy Nash have suggested that such an approach is appropriate in the jurisdictional context, where other, non-economic interests have less relevance. See Nash, supra note 10, at 529 n.74 ("The choice between rules and standards as democracy enhancing does not seem to weigh heavily in either direction in the context of jurisdictional boundaries."); Preis, supra note 10, at $170 \mathrm{n} .110$ (arguing that "noneconomic perspectives on" rules and standards "contribute comparatively little" to a discussion of district court subject matter jurisdiction, because such jurisdiction "do[es] not regulate primary conduct, but rather regulate[s] the forum for resolving disputes over primary conduct").

102 Although some writing about rules and standards has expressed a categorical preference for one, see, e.g., Antonin Scalia, The Rule of Law as a Law of Rules, 56 U. CHI. L. REV. 1175, 1178 (1989), much of the literature recognizes that the superiority of a rule or standard can be decided only in context, see Grodin, supra note 94, at 572; Kaplow, supra note 94, at 596; Sunstein, supra note 94, at 1016. 
rules and standards literature has sometimes noted, can help judges learn about the operation of the law. The traditional story of learning through standards is one of refinement. A court is faced with a new legal issue, and it must decide how it should articulate doctrine to address it. The court might prefer a clear rule because, for example, the context is one in which clarity and predictability are especially valued. Yet the court might also believe that clarity and predictability are not so important to require a rule, any rule, immediately. The court might instead want only an "appropriate" rule-one whose benefits (clarity and predictability) outweigh its costs (the substantive injustice of overand underinclusion).

When first faced with such an issue, a court might lack the information necessary to fashion an appropriate rule. It might not know, for example, what factual considerations are relevant to attaining a given purpose; the situation might be too novel or uncertain. ${ }^{103}$ And the court might have no means for discovering ex ante all the relevant considerations. In such cases, it will be impossible for the court to fashion an appropriate rule in the first instance.

The court might accordingly decide to use a standard. ${ }^{104}$ This is not only because a standard is all that is left. A standard might also help accumulate the information necessary to craft an appropriate rule. By initially employing a standard - its "broad-ranging factual inquiry" not limiting the information considered - the court can consider the entire universe of facts that may further a particular purpose. ${ }^{105}$ With repeated application of this standard, patterns will likely emerge. Certain facts, for example, will appear consistently relevant to furthering a given purpose, and others consistently irrelevant. ${ }^{106}$ Repeated use of the standard thus reveals relevant factual considerations for fashioning an appropriate rule.

As more cases are decided and the pool of information grows, the benefits of continuing to use the standard likely diminish. ${ }^{107}$ Each application of the standard might illustrate some additional information, but there will generally come a point at which the standard is no longer needed. This could be because the benefit of gleaning additional information will outweigh the cost. Or the court could believe it has accumulated sufficient information to craft an

${ }^{103}$ See Scott Baker \& Pauline Kim, A Dynamic Model of Doctrinal Choice, 4 J. LEGAL ANALYSIS 329, 343 (2012).

104 See id.

105 Ehrlich \& Posner, supra note 94, at 266.

${ }^{106} \mathrm{Id}$; Kennedy, supra note 94 , at 1706 . As a simplified example, a court might first encounter a case in which facts $\mathrm{A}, \mathrm{B}$, and $\mathrm{C}$ are present, and it determines that outcome $\mathrm{X}$ would best serve a given purpose. In the next case, with facts $A, B$, and $D$, the court might determine that outcome $Y$ is preferred. And in a third case, with facts $C, D$, and $E$, outcome $\mathrm{X}$ might again be best. These cases begin to suggest what facts are relevant (e.g., the presence or absence of C) to attaining a given purpose.

${ }^{107}$ Ehrlich \& Posner, supra note 94, at 266. 
appropriate rule. ${ }^{108}$ At such points, the court can transition from a standard to a rule. 109

This is a commonly recognized use of standards to facilitate judicial learning. This concept of judicial learning is limited, however, by its focus on a single court. Many discussions of judicial learning through the use of standards implicitly envision a single court that is presumably bound by stare decisis. ${ }^{110}$ The court initially announces a standard that it then refines, cutting off the less relevant factual considerations until it reaches a rule. Importantly, this single court presumably moves in only a single direction-that is, tries only one approach-at any given time. And this is normally toward the ultimate rule. Granted, some of the steps along that path might be inconsistent with one another, moving in fits and starts. But notions of stare decisis limit the number of approaches a single court can take at any given time.

\section{Standards and Multi-court Experimentation}

The literature on rules and standards has thus recognized an important way in which standards can facilitate judicial learning. But by focusing on a single court, the literature has not recognized standards' full potential. Expanding the analysis to include a single upper court (such as the United States Supreme Court) and multiple courts (such as the several circuits of the United States courts of appeals) reveals another way of using standards to accumulate information relevant to fashioning legal doctrine.

In the federal judiciary, this multi-court use of standards to experiment would work as follows. The Supreme Court adopts a standard for a particular legal problem, and it pitches that standard at a relatively high level of generality. Such a standard would by definition provide a range of acceptable

${ }^{108}$ Id.; Kennedy, supra note 94, at 1706.

${ }^{109}$ Holmes's discussion of negligence illustrates this concept of learning through standards in the context of negligence. See Oliver WENDELl HOLMES, JR., THE COMMON LAw 120-29 (1881). Negligence is a standard. See id. at 124. Holmes noted that in some cases, judges would send a set of facts - even undisputed facts-to a jury for determination of a party's alleged negligence. See id. at 125 . Holmes argued that such a judge thought that a jury, relying on its everyday experience, could determine what constitutes negligence. See $i d$. at 125 . In effect, the jury uses its experience to determine the legal question of whether a party's conduct was negligent. See id. at 126-27. Over time, judges would learn from this procedure what the community deemed negligent and what it did not. See $i d$. at 127 . Rather than continue to send the same factual scenario to a jury, the judge would then rule that there was or was not negligence as a matter of law. See id. at 129.

${ }^{110}$ Scott Baker and Pauline Kim have expanded beyond the single-court analysis to explore the transition from standards to rules in a hierarchical court system. See generally Baker \& Kim, supra note 103 . They modeled a situation in which an upper court initially articulates a standard for a given legal problem; a lower court then applies that standard by incorporating new and unforeseen information into the decision calculus. Id. at 345 . Baker and Kim limited their analysis, however, to interaction between a single upper and lower court. Id. at 354 . 
ways to resolve the problem. The courts of appeals would then be tasked with applying that standard to subsequent cases. And because the standard allows for a range of acceptable resolutions, the different circuits of the courts of appeals might develop different approaches to resolving this single problem, perhaps even refining the standard into different rules. (Something akin to this can be seen in circuit splits over the interpretation of a Supreme Court decision.)

The courts of appeals would then repeatedly apply their different approaches to cases that come before them, and notions of precedent and stare decisis would likely provide some consistency in application. Repeated application of these different approaches within the different circuits would generate evidence as to their consequences. And because multiple courts would simultaneously apply their different rules, the generation of this evidence would be more rapid than that generated by a single court.

If a split between the circuits persisted, the courts of appeals could resolve it themselves. Courts on one side of the split might determine that their approach had unforeseen or undesirable consequences, or they might determine that the approach taken by other courts had superior consequences. These courts might then sit en banc to reevaluate the approach they took. In doing so, they could rely on the experiences of the various circuits. Alternatively, the Supreme Court could step in and resolve the split. And when it did so, the Court could choose to base its decision on the evidence generated in the courts of appeals.

This multi-court focus captures the courts of appeals' ability to rapidly and simultaneously generate information on the consequences of different approaches to a single issue. Such an approach might be particularly fruitful in the context of interlocutory appeals, as set forth in the next Part.

\section{EXPERIMENTING WITH A REIMAGINED COLLATERAL ORDER DOCTRINE}

As set out above, interlocutory appellate reform could benefit from some means of generating evidence about the consequences of different rules; judicial experimentation might be a particularly appropriate way of generating that evidence in this context; and in a hierarchical court system like the federal judiciary, the use of a standard could facilitate such experimentation. This Part illustrates one way that judicial experimentation through standards could work in the interlocutory appeals context.

I propose a modest means for accomplishing this-relaxing the requirements of the current collateral order exception to the final judgment rule. I propose this specific approach for two reasons. First, it's more likely, as the history of the two major proposed interlocutory appeal reforms indicates. Switching to a regime of entirely discretionary review would be a radical change in appellate procedure that might even require an act of Congress. ${ }^{111}$

${ }^{111}$ But see Steinman, supra note 3, at 1278-80 (arguing that the All Writs Act currently allows for discretionary appeals). 
Despite several decades of arguments for discretionary appeals, ${ }^{112}$ no such reform appears on the horizon. A wholesale switch to categorical rules also seems unlikely. To be sure, the Supreme Court has recently endorsed the use of rulemaking to define appealable interlocutory orders, ${ }^{113}$ leading some to suggest that judicial exceptions to the final judgment rule are things of the past. ${ }^{114}$ The courts of appeals nevertheless continue to hold that new types of interlocutory orders can be immediately appealed. ${ }^{115}$ And the Supreme Court's power to define through rulemaking those orders that can be immediately appealed has laid largely dormant; ${ }^{116}$ since Congress gave the Court this power in the early $1990 \mathrm{~s}$, it has used it only once, to permit appeals of class certification decisions. ${ }^{117}$ Second, a modest reform of the collateral order doctrine is feasible. As explained below, one can already find hints of a relaxed, standardlike approach to collateral orders in a few judicial opinions, and there exists at least one historical example of the courts of appeals learning through

112 See, e.g., Cooper, supra note 4, at 163-64; Eisenberg \& Morrison, supra note 4, at 293-302; Redish, supra note 4, at 124-27; Nagel, supra note 4, at 214-22.

113 See Mohawk Indus., Inc. v. Carpenter, 130 S. Ct. 599, 609 (2009). Mohawk specifically addressed the collateral order doctrine. The Court emphasized the narrow scope of the doctrine as well as the alternative of rulemaking. See id. Concurring, Justice Thomas suggested that the Court draw a line in the sand and hold that there would be no more additions to the catalogue of appealable collateral orders. See id. at 610 (Thomas, J., concurring in part and concurring in the judgment).

${ }^{114}$ Many have read Mohawk as indicating that few (if any) orders will be found collaterally appealable in the future. See Erwin Chemerinsky, Court Keeps Tight Limits on Interlocutory Review, TRIAL, Mar. 2010, at 52, 54 ("[Mohawk] shows that little, if anything, will be found to fit within the collateral order exception that the Court recognized in Cohen."); James E. Pfander, Iqbal, Bivens, and the Role of Judge-Made Law in Constitutional Litigation, 114 PENN. ST. L. REV. 1387, 1404 (2010) ("[T]he Court [in Mohawk]... suggested that it would no longer adopt judge-made expansions of the collateral order doctrine."); Pfander \& Krohn, supra note 4, at 1053; Rory Ryan, Luke Meier \& Jeremy Counseller, Interlocutory Review of Orders Denying Remand Motions, 63 BAYLOR L. REv. 734, 776 (2011) (suggesting that after Mohawk, "little room exists for the [collateral order] doctrine's expansion"); see also Glynn, supra note 4, at 212 (suggesting, in 2001, that expansion of the collateral order doctrine had been "effectively preclude[d]" by doctrinal developments); Petty, supra note 4, at 362, 394. But see Dodson, supra note 10, at 42 ("[T]he Court [in Mohawk] has left open the possibility that other nonfinal decisions might be deemed final.").

115 See Chehazeh v. Att'y Gen., 666 F.3d 118, 136 (3d Cir. 2012); United States v. Mitchell, 652 F.3d 387, 398 (3d Cir. 2011) (en banc); Bank of Am., N.A. v. Veluchamy, 643 F.3d 185, 188 (7th Cir. 2011); Montez v. Hickenlooper, 640 F.3d 1126, 1133 (10th Cir. 2011); Godin v. Schencks, 629 F.3d 79, 84-85 (1 st Cir. 2010).

${ }^{116}$ Under 28 U.S.C. $\$ 2072$ (c) (2006), the Supreme Court can create rules of procedure that "define when a ruling of a district court is final for the purposes of appeal under [§ 1291]." And under 28 U.S.C. $§ 1292(e)$ (2006), those rules can also "provide for an appeal of an interlocutory decision to the courts of appeals that is not otherwise provided for" in $\S 1292$. In other words, the Supreme Court can prescribe rules allowing for certain district court orders to be immediately appealed.

${ }^{117}$ See FED. R. CIV. P. 23(f). See generally Martineau, supra note 4. 
experimentation in the context of interlocutory appeals. In short, the courts could do this.

This Part first explores the current state of the collateral order exception, revealing its limited usefulness in facilitating multi-court experimentation. It then turns to reimagining the collateral order doctrine as more standard-like, relaxing the requirements to create room for different approaches to a single issue. Finally, this Part briefly addresses the potential for a similar "percolative" approach in other procedural and jurisdictional contexts.

\section{A. The Inadequacy of the Current Collateral Order Exception}

The collateral order exception started out simple enough. ${ }^{118}$ In Cohen $v$. Beneficial Loan Corp., the Supreme Court held that a district court's order refusing to apply a New Jersey law in a diversity case was immediately appealable. ${ }^{119}$ The New Jersey statute required plaintiffs in shareholder derivative suits to post a bond before proceeding, thereby guaranteeing that they could, if unsuccessful, pay the defense's costs and fees. ${ }^{120}$ The corporation appealed this interlocutory decision, and the Supreme Court deemed the order immediately appealable. It held that the district court's order "appear[ed] to fall

118 Some may take issue with my calling the collateral order doctrine an "exception" to the final judgment rule, as there is some debate over whether that is a proper characterization. The Supreme Court used to call the doctrine an exception to $\S 1291$ but has more recently denied as much, instead characterizing it as a "practical construction" of that statute. Compare Richardson-Merrell, Inc. v. Koller, 472 U.S. 424, 430 (1985) ("Section 1291 accordingly provides jurisdiction for this appeal only if orders disqualifying counsel in civil cases fall within the 'collateral order' exception to the final judgment rule."), and Firestone Tire \& Rubber Co. v. Risjord, 449 U.S. 368, 374 (1981) ("Our decisions have recognized ... a narrow exception to the requirement that all appeals under $\S 1291$ await final judgment on the merits.”), with Digital Equip. Corp. v. Desktop Direct, Inc., 511 U.S. 863,867 (1994) ("The collateral order doctrine is best understood not as an exception to the 'final decision' rule laid down by Congress in $\S 1291$, but as a 'practical construction' of it." (citation omitted)), and Will v. Hallock, 546 U.S. 345, 349 (2006) (same). To the extent this debate over the collateral order doctrine's proper characterization is relevant, I suspect it relates only to debates over the doctrine's legitimacy. See Martineau, supra note 4, at 776; Steinman, supra note 3, at 1256. But see Solimine, supra note 4, at 1184. Some contend, for example, that courts shouldn't create exceptions to the jurisdictional boundaries Congress has drawn, see Martineau, supra note 4 , at 776 , so the collateral order doctrine must stem from an interpretation of a jurisdictional statute for it to be legitimate. But if it is supposed to be an interpretation, some question whether one can plausibly get the collateral order doctrine from the language of $\S 1291$-they ask how the courts can legitimately treat orders that are clearly not "final" in the everyday sense of the word as "final" for purposes of $\S 1291$. Steinman, supra note 3, at 1252. Although these issues (the proper characterization of the doctrine and its relation to the word "final" in $\S 1291$ ) could conceivably be relevant when fashioning the scope and substance of the collateral order doctrine, they largely address whether the doctrine should exist at all. This Article is not concerned with this issue, taking the doctrine's existence as a given.

119337 U.S. $541,546-47$ (1949).

120 Id. at $544-45$. 
in that small class which finally determine claims of right separable from, and collateral to, rights asserted in the action, too important to be denied review and too independent of the cause itself to require that appellate consideration be deferred until the whole case is adjudicated." 121

Out of Cohen grew the collateral order doctrine.122 As the case law developed, the collateral order exception transformed from a vague standard into a strict rule. ${ }^{123}$ Cohen and the cases immediately following it did not clearly say what was required for an immediate appeal; they instead asked only whether the order was "too important to be denied review and too independent of the cause itself to require that appellate consideration be deferred."124 In Coopers \& Lybrand $v$. Livesay, however, the Supreme Court refined the requirements for a collateral order appeal into a three-part test-for a district court order to be immediately appealable, it must:

(1) "conclusively determine the disputed question,"

(2) "resolve an important issue completely separate from the merits of the action, and"

$121 \mathrm{Id}$. at 546.

122 See generally Mohawk Indus., Inc. v. Carpenter, 130 S. Ct. 599 (2009); Ashcroft v. Iqbal, 556 U.S. 662 (2009); Osborn v. Haley, 549 U.S. 225 (2007); Will v. Hallock, 546 U.S. 345 (2006); Sell v. United States, 539 U.S. 166 (2003); Cunningham v. Hamilton Cnty., 527 U.S. 198 (1999); Quackenbush v. Allstate Ins. Co., 517 U.S. 706 (1996); Behrens v. Pelletier, 516 U.S. 299 (1996); Johnson v. Jones, 515 U.S. 304 (1995); Swint v. Chambers Cnty. Comm'n, 514 U.S. 35 (1995); Digital Equip. Corp. v. Desktop Direct, Inc., 511 U.S. 863 (1994); P.R. Aqueduct \& Sewer Auth. v. Metcalf \& Eddy, Inc., 506 U.S. 139 (1993); Lauro Lines S.R.L. v. Chasser, 490 U.S. 495 (1989); Midland Asphalt Corp. v. United States, 489 U.S. 794 (1989); Van Cauwenberghe v. Biard, 486 U.S. 517 (1988); Gulfstream Aerospace Corp. v. Mayacamas Corp., 485 U.S. 271 (1988); Stringfellow v. Concerned Neighbors in Action, 480 U.S. 370 (1987); Mitchell v. Forsyth, 472 U.S. 511 (1985); Richardson-Merrell, Inc. v. Koller, 472 U.S. 424 (1985); Flanagan v. United States, 465 U.S. 259 (1984); Moses H. Cone Mem'l Hosp. v. Mercury Constr. Corp., 460 U.S. 1 (1983); United States v. Hollywood Motor Car Co., 458 U.S. 263 (1982); Nixon v. Fitzgerald, 457 U.S. 731 (1982); Helstoski v. Meanor, 442 U.S. 500 (1979); United States v. MacDonald, 435 U.S. 850 (1978); Coopers \& Lybrand v. Livesay, 437 U.S. 463 (1978); Abney v. United States, 431 U.S. 651 (1977); Eisen v. Carlisle \& Jacquelin, 417 U.S. 156 (1974); Roberts v. U.S. Dist. Court for N. Dist. of Cal., 339 U.S. 844 (1950); Swift \& Co. Packers v. Compania Colombiana del Caribe, 339 U.S. 684 (1950).

123 Federal courts scholarship largely regards the collateral order doctrine as rule-like. See Glynn, supra note 4, at 217; Martineau, supra note 4, at 773; Solimine, supra note 4, at 1213. But see Solimine \& Hines, supra note 4, at 1572 (calling the collateral order doctrine a hybrid, where a general standard-like approach eventually yields rules).

124337 U.S. at 546; see, e.g., Stack v. Boyle, 342 U.S. 1, 6-7 (1951); Roberts v. U.S. Dist. Court, 339 U.S. 844, 845 (1950); Swift \& Co. Packers v. Compania Colombiana del Caribe, 339 U.S. 684, 688-89 (1950); see also McConnell, supra note 4, at 455 ("The Court failed in many [cases after Cohen] to make explicit the factors it considers in deciding whether interlocutory orders are appealable under section 1291."). 
(3) "be effectively unreviewable on appeal from a final judgment."125

This test is, to be sure, not a radical semantic departure from Cohen. ${ }^{126}$ But with this new formula, the Court moved from a standard to a rule for collateral order cases. Rather than the vague suggestion that an order be "too important" and "too independent" to defer review, Coopers \& Lybrand asked a much more precise question. The three requirements became strict preconditions to appeal; courts are to apply them stringently, and the absence of any one requirement answers the question against appealability. 127

This strict approach to collateral order appeals does little to facilitate experimentation. The requirements are substantially underinclusive, and that underinclusiveness limits judicial experimentation. The multi-court experimentation just described works best with some disuniformity among the circuits; courts need to adopt different approaches to a single question if they are to simultaneously generate evidence as to the consequences of those different approaches. The three collateral order requirements, along with the necessity that they all be present, narrow the range of possible decisions that courts can reach. And this limit comes without substantial countervailing benefits.

Consider the requirement that an order be "completely separate" from the merits to be appealable. This requirement's purpose is presumably to avoid

${ }^{125}$ Coopers \& Lybrand v. Livesay, 437 U.S. 463, 468 (1978) (numbering added); accord Johnson v. Jones, 515 U.S. 304, 310-11 (1995) (noting that the Court in Coopers \& Lybrand "restated Cohen as requiring that" an appealable order meet these three requirements); Van Cauwenberghe v. Biard, 486 U.S. 517, 522 (1988) ("The Court refined the 'collateral order' doctrine of Cohen in Coopers \& Lybrand v. Livesay." (citation omitted)); see also Will v. Hallock, 546 U.S. 345, 349 (2006) (noting that "[t]he requirements for collateral order appeal have been distilled down to [these] three conditions"); Gulfstream Aerospace Corp. v. Mayacamas Corp., 485 U.S. 271, 276 (1988) (describing the Coopers \& Lybrand requirements as the "three-pronged test to determine whether an order that does not finally resolve a litigation is nonetheless appealable under $\S 1291 ")$.

${ }^{126}$ Cohen described appealable collateral orders as those that "finally determine claims of right separable from, and collateral to, rights asserted in the action, too important to be denied review and too independent of the cause itself to require that appellate consideration be deferred until the whole case is adjudicated." 337 U.S. at 546.

${ }^{127}$ See Mohawk Indus., Inc. v. Carpenter, 130 S. Ct. 599, 605 (2009); Osborn v. Haley, 549 U.S. 225, 238 (2007); Will v. Hallock, 546 U.S. 345, 349 (2006); Sell v. United States, 539 U.S. 166, 176 (2003); Cunningham v. Hamilton Cnty., 527 U.S. 198, 204 (1999); Johnson v. Jones, 515 U.S. 304, 310-11 (1995); Swint v. Chambers Cnty. Comm'n, 514 U.S. 35, 42 (1995); Lauro Lines S.R.L. v. Chasser, 490 U.S. 495, 498 (1989); Midland Asphalt Corp. v. United States, 489 U.S. 794, 799 (1989); Van Cauwenberghe v. Biard, 486 U.S. 517, 522 (1988); Gulfstream Aerospace Corp. v. Mayacamas Corp., 485 U.S. 271, 276 (1988); Stringfellow v. Concerned Neighbors in Action, 480 U.S. 370, 375 (1987); Richardson-Merrell, Inc. v. Koller, 472 U.S. 424, 431 (1985); Moses H. Cone Mem'l Hosp. v. Mercury Constr. Corp., 460 U.S. 1, 11 (1983); United States v. Hollywood Motor Car Co., 458 U.S. 263, 266 (1982); Firestone Tire \& Rubber Co. v. Risjord, 449 U.S. 368, 375 (1981). 
interlocutory appeals in which issues would overlap with the ultimate merits of the case. The extent of such overlap is certainly relevant when determining whether an order should be immediately appealable; an appeal after final judgment often involves a review of the merits, so the closer an interlocutory issue is to the merits, the greater the risks of repetitive review. Substantial overlap also risks interference with matters traditionally left to the district court, since merits issues are presumably to be resolved first in the district court. This can lead to friction between federal appellate and district judges as well as delays in trial court proceedings.

If the "completely separate" requirement means what it says, however, the range of tolerable overlap is quite narrow - any overlap with the merits would seem to answer the question against appealability. The "completely separate" requirement thus limits the approaches that courts can take to the appealability of particular issues.

This limit seems unnecessary. It is at least conceivable that in some cases some overlap should be tolerated. Indeed, requiring that an order have absolutely no connection to the merits seems unnecessarily harsh when a lack of immediate review would result in an immense and irreparable harm. ${ }^{128}$ Surely courts could tolerate some overlap with the merits in such a case. And in practice, they sometimes do; qualified immunity appeals are the prime example. ${ }^{129}$ Outside of the collateral order context, other exceptions to the final judgment rule tolerate or even embrace some overlap; interlocutory review of class certification "will entail some overlap with the merits of the plaintiff's

${ }^{128}$ See Palmer v. City of Chicago, 806 F.2d 1316, 1318 (7th Cir. 1986) (Posner, J.).

${ }^{129}$ Under the doctrine of qualified immunity, government officials in constitutional tort suits are immune from damages so long as they did not violate a "clearly established" constitutional right. See Harlow v. Fitzgerald, 457 U.S. 800, 818 (1982). In Mitchell v. Forsyth, 472 U.S. 511, 530 (1985), the Supreme Court held that public officials could immediately appeal a pretrial denial of this immunity. The Mitchell Court acknowledged that "resolution of [qualified immunity] will entail consideration of the factual allegations that make up the plaintiff's claim for relief." Id. at 528. But the Court concluded:

[A] claim of immunity is conceptually distinct from the merits of the plaintiff's claim that his rights have been violated.... An appellate court reviewing the denial of the defendant's claim of immunity need not consider the correctness of the plaintiff's version of the facts, nor even determine whether the plaintiff's allegations actually state a claim.

Id. at 527-28. The denial of qualified immunity was thus deemed sufficiently separate from the merits. Similar overlap is possible in reviewing the denial of Double Jeopardy and Speech \& Debate Clause immunity, both of which the Supreme Court had previously held to be appealable collateral orders. See Helstoski v. Meanor, 442 U.S. 500, 506-08 (1979); Abney v. United States, 431 U.S. 651, 662 (1977). 
underlying claim," 130 and interlocutory review of injunctive relief requires an assessment of the likelihood of success on the merits. ${ }^{131}$

More often than not, however, courts treat the collateral order requirement that an order be "completely separate" from the merits to mean what it says-an order must have no bearing on the merits of a case to be appealable. There are only so many ways to answer the question of whether an order is "completely separate," and this limited range of answers inhibits disuniformity among the courts of appeals. Thus, to the extent courts feel bound by the "completely separate" requirement, it limits judicial experimentation.

The requirement that an order be "effectively unreviewable" has similar problems. This requirement's purpose is generally to avoid some harms that would occur absent an immediate appeal. Like overlap with the merits, considerations of harm should factor into the appealability calculus; the greater the potential harm, the greater the benefit of an interlocutory appeal.

With a few exceptions, however, the Supreme Court has suggested that irreparable harm alone is not enough for an order to satisfy this requirement; 132 "the mere identification of some interest that would be 'irretrievably lost' has never sufficed to meet the third Cohen requirement." 133 The lack of immediate

${ }^{130}$ Wal-Mart, Inc. v. Dukes, 131 S. Ct. 2541, 2551 (2011); see also id. (adding that this "cannot be helped").

${ }^{131}$ See, e.g., Ezell v. City of Chicago, 651 F.3d 684, 694 (7th Cir. 2011) ("To win a preliminary injunction, a party must show that it has (1) no adequate remedy at law and will suffer irreparable harm if a preliminary injunction is denied and (2) some likelihood of success on the merits.").

132 The meaning of this requirement has shifted over the years as the Supreme Court has taken various approaches to defining it. In some cases, the Court seems to ask whether the issue being appealed would become moot by the end of the district court proceedings; were it to become moot, there would be no appellate review. See Stack v. Boyle, 342 U.S. 1, 6-7 (1951); Swift \& Co. Packers v. Compania Colombiana del Caribe, 339 U.S. 684, 688-89 (1950); Cohen v. Beneficial Loan Corp., 337 U.S. 541, 545-46 (1949). Other times the Court appears to ask whether the party seeking appeal will suffer irreparable harm without immediate review; the greater the harm, the more likely the order is "effectively unreviewable." See Johnson v. Jones, 515 U.S. 304, 311 (1995) ("The requirement that the issue underlying the order be 'effectively unreviewable' later on ... means that failure to review immediately may well cause significant harm."). Still other times the Supreme Court asks whether an important right-such as a right to be free from the burdens of trial-would be imperiled absent immediate appeal. See Osborn v. Haley, 549 U.S. 225, 238-39 (2007); Will v. Hallock, 546 U.S. 345, 353 (2006); Digital Equip. Corp. v. Desktop Direct, Inc., 511 U.S. 863, 869-71 (1994); P.R. Aqueduct \& Sewer Auth. v. Metcalf \& Eddy, Inc., 506 U.S. 139, 145-46 (1993); Lauro Lines S.R.L. v. Chasser, 490 U.S. 495, 499-501 (1989); Mitchell v. Forsyth, 472 U.S. 51 1, 526-27 (1985); Nixon v. Fitzgerald, 457 U.S. 731, 742-43 (1982); Helstoski v. Meanor, 442 U.S. 500, 506-08 (1979); United States v. MacDonald, 435 U.S. 850, 860-61 (1978); Abney v. United States, 431 U.S. 651, 660-62 (1977); see also Gerdy, supra note 4 , at 235,242 (contending that the Court has "not uniformly or even consistently analyzed what it means to be "unreviewable" and "fail[ed] to explain precisely [what] alternative is acceptable or the circumstances in which each line is preferred or even necessary").

133 Digital Equip. Corp., 511 U.S. at 872. 
review must instead "imperil a substantial public interest" or "some particular value of a high order." 134 In other words, lack of appeal must threaten a special systemic interest, not an individual one.

Such a specific requirement again limits the number of ways in which the courts of appeals can decide the issue of appealability. And again, doing so seems unnecessary. Considerations of harm, any kind of harm, appear in several other exceptions to the final judgment rule. ${ }^{135}$ The collateral order doctrine's requirement that a special systemic interest be harmed ignores cases in which the benefit of preventing a non-special harm outweighs the cost of permitting appeal.

In short, the current collateral order doctrine is rule-like, and like many rules it has a limited range of acceptable ways to resolve a problem. To the extent courts feel bound by the current rule-like approach, they are discouraged from experimenting. If the collateral order doctrine is to foster experimentation, it needs to be relaxed.

\section{B. Relaxing the Collateral Order Requirements}

A more standard-like approach to collateral order appeals would broaden the range of acceptable decisions and thus facilitate experimentation among the courts of appeals. The use of standards alone, however, does not inevitably lead to robust experimentation. Courts must also evaluate the consequences of any given approach with a readiness to revisit the issue once those consequences are known. The changes would need to be both doctrinal and functional. I address each of these changes in turn.

Doctrinally, the collateral order exception would essentially return to the original statement in Cohen - an order must be "too important to be denied review and too independent of the cause itself to require that appellate consideration be deferred." 136 In other words, courts would ask whether the benefit of an immediate appeal for a type of order outweighs the costs. This is admittedly vague. But this vagueness is a virtue; it not only permits the sort of experimentation discussed in this Article, but also allows courts to consider a variety of things that are relevant to the question of whether to allow an immediate appeal. ${ }^{137}$

${ }^{134}$ Mohawk Indus., Inc. v. Carpenter, 130 S. Ct. 599, 605 (2009) (quoting Will v. Hallock, 546 U.S. 345, 352-53 (2006)).

${ }^{135}$ See, e.g., 28 U.S.C. $\S 1292(a)(1)$ (2006) (permitting appeal of orders regarding injunctive relief, review of which requires considering irreparable harm, see supra note 131); 28 U.S.C. $\$ 1651$ (authorizing writs of mandamus, which are available when the party seeking the writ "proves irreparable harm ... and a clear right to the relief sought," Am. Bank v. City of Menasha, 627 F.3d 261, 264 (7th Cir. 2010) (internal quotation marks omitted)).

${ }^{136}$ Cohen, 337 U.S. at 546.

${ }^{137}$ Under the approach I envision, courts would retain the current collateral order exception's requirement of largely categorical decision making. The Supreme Court 
For example, a standard-like approach would take a much less strict approach to considerations of overlap and harm. As discussed above, there is little reason to require complete separation from the merits. Rather than strictly require that an order be "completely separate," a more standard-like approach could ask whether an order was "sufficiently" separate, thereby encouraging courts to tolerate some overlap when other interests weigh in favor of permitting an appeal. And as to harm, the greater the harm-whatever the interest harmed-the greater the need for an immediate appeal to avoid that harm.

Other considerations would also be relevant, such as the likelihood of district court reconsideration. If a district court is likely to revisit a decision, the need for immediate review is lower; the would-be appellant might be satisfied after the revisiting, and an unnecessary appeal would be averted. This consideration thus saves appellate courts from entering a dispute when a district court might later render appellate review unnecessary. And the likelihood of reconsideration would be only one consideration among many. There could be types of orders that a district court is only marginally likely to revisit, but if the other interests favoring immediate appeal are slight this minor likelihood might be enough to answer the question against appealability. There might also be

currently requires that courts reach a categorical decision on whether that type of order, as a class, should be appealable; the allowance or denial of an appeal extends to all cases, not just the case before it. See Cunningham v. Hamilton Cnty., 527 U.S. 198, 206 (1999); Digital Equip. Corp. v. Desktop Direct, Inc., 511 U.S. 863, 868 (1994). This categorical requirement is troubling under the current state of the law, as it asks courts to make a generally pragmatic assessment of the costs and benefits of immediate appeal based on limited data-the particular case before the court. If subsequent experience reveals that the assumptions underlying that initial decision were flawed (and they very well could be, considering the limited information the court had when making the decision), the current collateral order exception does not invite reconsideration. Under an experimental approach, however, the categorical requirement is less troubling. The experimentation discussed in this Article needs some sort of stare decisis; courts need to stick to an approach for some time if they are to generate evidence as to its effects. Accordingly, requiring a categorical decision the first time an issue arises could foster experimentation, as it would provide a rule that the court would stick with, at least for some time. It should be noted, however, that the current categorical requirement is not as constricting as the doctrine might indicate, as the courts of appeals do not appear to adhere too strictly to the categorical approach. Indeed, some courts of appeals decisions are rife with non-categorical, case-specific reasoning. See generally Harris v. Kellogg Brown \& Root Servs., Inc., 618 F.3d 398 (3d Cir. 2010); United States v. Romeo-Ochoa, 554 F.3d 833 (9th Cir. 2009); McMahon v. Presidential Airways, Inc., 502 F.3d 1331 (11th Cir. 2007); United States v. Moussaoui, 483 F.3d 220 (4th Cir. 2007); Houston Cnty. Hosp. v. Blue Cross \& Blue Shield of Tex., Inc., 481 F.3d 265 (5th Cir. 2007); Pierce v. Blaine, 467 F.3d 362 (3d Cir. 2006); Goodman v. Harris Cnty., 443 F.3d 464 (5th Cir. 2006); ADAPT of Phil. v. Phil. Hous. Auth., 417 F.3d 390 (3d Cir. 2005); Baldridge v. SBC Commc'ns, Inc., 404 F.3d 930 (5th Cir. 2005); Competitive Tech., Inc. v. Fujitsu Ltd., 374 F.3d 1098 (Fed. Cir. 2004); United States v. Hickey, 367 F.3d 888 (9th Cir. 2004). 
types of orders that present a fair chance of reconsideration but so merit immediate review that these chances are overborne. ${ }^{138}$

The previous three considerations map nicely onto the traditional three requirements for collateral order appeals (that an order be conclusive, separate, and effectively unreviewable); they are simply more standard-like approaches to them. But other costs and benefits of allowing an immediate appeal should also be considered. A court taking this approach would need to consider the likelihood of district court errors, the need to address an underdeveloped area of the law that rarely reaches an appeal due to settlement before final judgment, the likely number of appeals, the potential for abuse given that litigants might use immediate appeals to harass other parties or delay proceedings, and potential alternative avenues for review. 139

Functionally, the more standard-like approach would permit the courts of appeals to adopt different rules as to the appealability of particular types of orders. For example, when first faced with the issue, one court of appeals might hold that denials of a government contractor's claim to derivative sovereign immunity are not immediately appealable collateral orders while another decides that they are. ${ }^{140}$ When initially reaching this decision, these courts would likely need to make some assumptions about the costs and benefits of permitting such appeals. They might guess at the potential increase in appeals by estimating the incidence of derivative sovereign immunity claims, and they might hypothesize about the need for immediate review by estimating how often district courts are likely to err in this context. These considerations and others are relevant to deciding whether denials of derivative sovereign immunity should be immediately appealed. But the direction and magnitude of these considerations-whether and how much they weigh for or against appealability - is unclear. The potential increase in appeals might be small or significant, and the courts of appeals might primarily reverse or affirm district court decisions. Because reasonable arguments can be made about the influence of each of these considerations, similarly reasonable arguments can be made that the general costs of permitting appeals in this context outweigh the benefits, and vice versa. Two courts of appeals could accordingly reach conflicting rules on this issue while still remaining consistent with a standard-like collateral order doctrine.

These courts could then repeatedly apply their rules and evaluate the consequences. The court permitting appeals would keep an eye on, for example,

138 Wright, Miller, and Cooper make a similar point when suggesting that conclusiveness "cannot be separated entirely from other elements of collateral order appeal doctrine." See 15A WRIGHT, MILLER \& COOPER, supra note 21, § 3911.1, at 378 ("If there is a risk of sufficient hardship, a generalized prospect of reconsideration should not defeat appeal.").

${ }^{139}$ Id. $\S 3911.3$, at 400 ("Cases permitting collateral order appeal should be evaluated in part by asking whether the alternative paths to appeal must be explored.").

${ }^{140}$ The appealability of such denials has recently been rejected by several courts. See, e.g., Martin v. Halliburton, 618 F.3d 476, 485 (5th Cir. 2010). 
the number of additional appeals, the delay in district court proceedings due to an appeal, whether and to what extent the court is seeing the same case more than once, and the incidence of reversible error. As this pool of information builds, the court can reassess the assumptions underlying its initial decision. If, for example, the increase in appeals was much greater than assumed, the court might sit en banc to reverse its earlier decision.

The court that denied appeals would have less to monitor, as few parties would seek a run-of-the mill review after being told that appeals were not available. But there would still be a chance for en banc reconsideration of that earlier decision. A more standard-like approach would invite such a move. Again, the court would have based its initial decision on some assumptions. Litigants seeking to overturn the court's initial rule would have an incentive to undermine those assumptions. Litigants could rely on the experience within that circuit, showing, for example, that most cases settle before a district court's decision in an undeveloped area of law can be appealed. Or litigants could look to the experience of other courts to demonstrate, for example, that another circuit has seen only a small increase in appeals.

The courts of appeals might therefore resolve any circuit splits on their own. If they don't, the Supreme Court could step in to resolve the matter. And when it did so, it would be able to base its decision on the evidence gathered in the courts of appeals. If the Supreme Court was willing to consider such evidence, litigants would have a strong incentive to gather and present it to the Court.

The more standard-like approach just described is feasible. On the doctrinal front, a switch to a standard-like collateral order doctrine would be only a modest reform. For one, the standard-like approach incorporates the existing collateral order requirements, albeit in a much looser form. Further, there is some support for this more standard-like approach in the case law. The additional considerations (such as the likelihood of district court error and the likely increase in appeals) are not completely foreign to collateral order cases; although it is not common, courts sometimes mention those considerations in their decisions. ${ }^{141}$ And every once in a while, a court will take a more standardlike approach to the collateral order doctrine. ${ }^{142}$ That all being said, most collateral order cases stick closely to the rule-like approach outlined above, and adopting a standard-like approach to collateral order cases would be a substantial change. Still, it would find some support in the existing case law.

Functionally, there is at least one historical example in which the courts of appeals took an experimental approach to the collateral order doctrine-denials

141 See, e.g., Mohawk Indus., Inc. v. Carpenter, 130 S. Ct. 599, 607 n.2 (2009) (discussing the incidence of district court error).

142 See generally Johnson v. Jones, 515 U.S. 304 (1995); Henry v. Lake Charles Am. Press, L.L.C., 566 F.3d 164, 172-73 (5th Cir. 2009) ("'A]lthough we sometimes speak of the three Cohen criteria as strict preconditions for appellate review, even a brief exploration of the case law reveals that they might better be regarded as guidelines in making the pragmatic determination of whether to allow an order to be immediately appealed." (citation omitted)). 
of motions to disqualify opposing counsel. When the issue first arose, most of the courts of appeals permitted the appeal of such orders. ${ }^{143}$ But experience eventually raised serious questions about the wisdom of this approach; some of the courts permitting appeals witnessed an influx of cases, substantial trial court delays, and litigants using disqualification motions to harass other parties. ${ }^{144}$ This experience led several courts to ultimately hold that denials of disqualification motions were not appealable. Indeed, two courts reversed earlier decisions permitting such appeals based, at least in part, on a negative experience allowing them.

A series of Second Circuit decisions best illustrate these events. After several decisions going each way on the issue, ${ }^{145}$ the Second Circuit eventually sat en banc in Silver Chrysler Plymouth, Inc. v. Chrysler Motors Corp. to unanimously hold that denials of disqualification motions were immediately appealable collateral orders. ${ }^{146} \mathrm{Within}$ six years, the court apparently realized it had made a mistake and it again sat en banc to reverse course. ${ }^{147}$ This reversal was due, at least in part, to the Second Circuit's experience with these appeals during the intervening period. ${ }^{148}$ Shortly after its first en banc decision, the

143 See Westinghouse Elec. Corp. v. Kerr-McGee Corp., 580 F.2d 1311, 1312 (7th Cir. 1978); Fred Weber, Inc. v. Shell Oil Co., 566 F.2d 602, 607 (8th Cir. 1977); MacKethan v. Peat, Marwick, Mitchell \& Co., 557 F.2d 395, 396 (4th Cir. 1977) (per curiam); Fullmer v. Harper, 517 F.2d 20, 21 (10th Cir. 1975) (per curiam); Greene v. Singer Co., 509 F.2d 750, 751 (3d Cir. 1971); Tomlinson v. Fla. Iron \& Metal, Inc., 291 F.2d 333, 334 (5th Cir. 1961),

${ }^{144}$ See 15A WRIGHT, MILLER \& COOPER, supra note 21, §3911 "The strongest arguments for denying appeal [of disqualification motions]... depended on practical experience with the rule permitting appeal[:] [s] everal courts of appeals had allowed appeals, and found that motions to disqualify were used more and more frequently as means of harassment and delay."). Edward H. Cooper once made a similar point. See Cooper, supra note 4 , at 158 . As noted above, Cooper suggested that "the structure of the relationships between trial courts and appellate courts must be rested on the lessons of experience." Id. And disqualification denials were a clear lesson of this:

For a few years, several courts of appeals were persuaded that appeal should lie from an order denying a motion to disqualify opposing counsel. Appeals proliferated, and with them suspicions that motions to disqualify had come to be prompted in part by purposes of delay or even harassment. Experience proved the appeal rule bad, and it was abandoned.

Id.

145 Compare, e.g., Harmar Drive-In Theatre, Inc. v. Warner Bros. Pictures, Inc., 239 F.2d 555, 556 (2d Cir. 1956) (holding that the denial of a disqualification motion is immediately appealable under Cohen), with Marco v. Dulles, 268 F.2d 192, 193 (2d Cir. 1959) (holding that the denial of a disqualification motion is not immediately appealable), and Fleischer v. Phillips, 264 F.2d 515, 517 (2d Cir. 1959) (same).

146496 F.2d 800, 805 (2d Cir. 1974) (en banc).

147 See Armstrong v. McAlpin, 625 F.2d 433, 437-38 (2d Cir. 1980) (en banc).

148 See id. at 438 (stating that while the proliferation of disqualification appeals and their attendant delay "by themselves [did] not justify a conclusion that Silver Chrysler was improperly decided, they [did] suggest that a careful reconsideration of the issue of appealability is appropriate"). 
filing -and subsequent appeal-of disqualification motions apparently multiplied; ${ }^{149}$ although they did not have precise statistics, "many members of [the Second Circuit] noted that the availability of an immediate appeal [had] seemingly contributed to the proliferation of disqualification motions and the use of such motions for purely tactical reasons, such as delaying the trial."150 While the court could not "determine with precision the amount of the increase in such motions, [it was] left with the clear impression that they [had] substantially grown in number." 151 The practical effects of allowing appeals of disqualification motions, the court recognized, were substantial delays in the district courts; proceedings froze in their tracks during the consideration (in the district court and on appeal) of these motions. ${ }^{152}$ For these reasons, the Second Circuit revisited its earlier decision, ultimately holding that denials of disqualification motions were not immediately appealable collateral orders. ${ }^{153}$

The Sixth Circuit's case law had a similar history. The Sixth Circuit initially held that denials of disqualification motions were immediately appealable in Melamed v. ITT Continental Baking Co. but, finding the record insufficient, remanded the case for an evidentiary hearing. ${ }^{154}$ By the time the Melamed case returned to the Sixth Circuit three years later, "the egregious delay which [had] occurred and may reoccur in similar cases" caused the court to reconsider its initial holding. ${ }^{155}$ The Sixth Circuit's "experience with [the Melamed] case, plus a careful review of authority... [on] the issue of appealability, show[ed] a great possibility of abuse of the motion to disqualify an opponent's counsel."156 The court also noted "[t]he experience of the Second Circuit since its decision in Silver Chrysler[,] ... grappling with a deluge of interlocutory appeals." 157 With these considerations in mind, the Sixth Circuit

${ }^{149}$ See id. at 437-38; see also Allegaert v. Perot, 565 F.2d 246, 247 (2d Cir. 1977); W.T. Grant Co. v. Haines, 531 F.2d 671, 672 (2d Cir. 1976); Lefrak v. Arabian Am. Oil. Co., 527 F.2d 1136, 1138-39 (2d Cir. 1975); Int'l Elect. Corp. v. Flanzer, 527 F.2d 1288, 1289 (2d Cir. 1975); J.P. Foley \& Co. v. Vanderbilt, 523 F.2d 1357, 1358 (2d Cir. 1975) (per curiam); Ceramco, Inc. v. Lee Pharm., 510 F.2d 268, 269 (2d Cir. 1975). But see Armstrong, 625 F.2d at 447 (Mulligan, J., concurring in part and dissenting in part) (expressing doubt as to the actual proliferation of disqualification appeals).

${ }^{150}$ Armstrong, 565 F.2d at 437 (majority opinion); see, e.g., W.T. Grant Co., 531 F.2d at 672 ("Once again this court is faced with an appeal from the denial by the district court of a motion to disqualify plaintiff's counsel."); Int'l Elect. Corp., 527 F.2d at 1289 ("We have been met recently with a number of appeals on matters involving the disqualification of lawyer-opponents.").

151 Armstrong, 565 F.2d at 437.

152 Id. at 438 .

153 Id. at 440 .

154534 F.2d 82, 84-85 (6th Cir. 1976) (per curiam).

155 Melamed v. ITT Cont'l Baking Co., 592 F.2d 290, 295 (6th Cir. 1979).

${ }^{156} \mathrm{Id}$.

${ }^{157}$ Id. at 295-96 (quoting Cmty. Broad. of Bos., Inc. v. FCC, 546 F.2d 1022, 1027 (D.C.

Cir. 1976) (per curiam)). 
concluded that denials of disqualification motions would no longer be immediately appealable within that circuit. ${ }^{158}$

Two appellate courts thus appear to have relied, at least in part, on their own experience to decide the appealability of denied motions to disqualify. 159 These events reveal the potential of an experimental approach to interlocutory appeals.

More recently, however, the Supreme Court refused to rely on a similar comparison between the circuits. In Mohawk Industries, Inc. v. Carpenter, the Court held that disclosure orders adverse to the attorney-client privilege were not immediately appealable collateral orders. ${ }^{160}$ The courts of appeals had divided on the issue, and while most circuits had held that such orders were not appealable, ${ }^{161}$ three-the Third, Ninth, and D.C. Circuits—had held that they were. ${ }^{162}$

One recurring issue in these cases was a "floodgates" argument based on courts' concern that deeming these orders appealable would result in a flood of appeals. In merits briefing before the Supreme Court, Mohawk Industries (the party arguing for appealability) and an amicus argued that experience in the three circuits permitting these orders had not caused a flood of appeals. ${ }^{163}$ According to that briefing, in the twelve years since the Third Circuit had held disclosure orders denying a claim of privilege were appealable collateral orders, it had apparently decided only six cases on the issue. ${ }^{164}$ The Ninth and D.C. Circuits had each faced only one appeal on the issue since their decisions. ${ }^{165}$

But in holding that these orders could not be immediately appealed, the Supreme Court indicated that these courts' experiences were irrelevant. ${ }^{166}$ The Court suggested that the small number of appeals in those courts might "be due

158 Id.

159 The D.C. Circuit pointed to the experience of the Second Circuit (but not its own) to hold that denials of disqualification motions are not immediately appealable collateral orders. See Cmty. Broad. of Bos., Inc. v. FCC, 546 F.2d 1022, 1027 (D.C. Cir. 1976) (per curiam).

160130 S. Ct. 599,609 (2009).

161 See Boughton v. Cotter Corp., 10 F.3d 746, 750 (10th Cir. 1993); Texaco Inc. v. La. Land \& Exploration Co., 995 F.2d 43, 43 (5th Cir. 1993); Chase Manhattan Bank, NA v. Turner \& Newall, PLC, 964 F.2d 159, 162 (2d Cir. 1992); Reise v. Bd. of Regents, 957 F.2d 293, 295 (7th Cir. 1992); Quantum Corp. v. Tandon Corp., 940 F.2d 642, 644 (Fed. Cir. 1991).

162 See In re Napster, Inc. Copyright Litig., 479 F.3d 1078, 1089 (9th Cir. 2007); United States v. Phillip Morris Inc., 314 F.3d 612, 621 (D.C. Cir. 2003); In re Ford Motor Co., 110 F.3d 954, 964 (3d Cir. 1997).

163 See Brief for Petitioner at 40, Mohawk Indus., Inc. v. Carpenter, 130 S. Ct. 599 (2009) (No. 08-678), 2009 WL 1155404, at *40; Brief of the Chamber of Commerce of the U.S. as Amicus Curiae in Support of Petitioner at 29-35, Mohawk Indus., Inc. v. Carpenter, 130 S. Ct. 599 (2009) (No. 08-678), 2009 WL 1263621, at*29-35 [hereinafter, Chamber of Commerce Amicus Brief].

164 See Chamber of Commerce Amicus Brief, supra note 163, at 31.

165 See id. at 33-34.

${ }^{166}$ Mohawk Indus., Inc. v. Carpenter, 130 S. Ct. 599, 609 (2009). 
to the fact that the practice in all three Circuits is relatively new and not yet widely known."167 The Court also suggested that were it to issue a decision allowing such appeals, "many more litigants would likely choose that route."168

The Court's suggestion is troubling from an experimental standpoint. The decision in Mohawk seemed to emphasize the importance of consequences; it concluded that "the limited benefits of applying 'the blunt, categorical instrument of $\S 1291$ collateral order appeal' to privilege-related disclosure orders simply cannot justify the likely institutional costs" because "[p]ermitting parties to undertake successive, piecemeal appeals of all adverse attorney-client rulings would unduly delay the resolution of district court litigation and needlessly burden the Courts of Appeals." 169 That is, the Court would not permit collateral appeals from these orders because doing so would cause too much delay and result in too many appeals. Thus, much like the literature on interlocutory appeals, the Court was consequence-focused. But it appeared to base its decision on speculation or hypothesized consequences, not the evidence of actual consequences that it had before it. To the extent courts read Mohawk to suggest that evidence of actual experience with interlocutory appeals should not influence collateral order decisions, it seems like a step in the wrong direction.

Even without Mohawk, however, the federal courts are still a ways away from experimenting with interlocutory appeals. The first step would be for the Supreme Court to relax the collateral order doctrine and send a signal to the courts of appeals that some experimentation is permissible. The courts of appeals would then need to step in to conduct the experiment and monitor the consequences. And litigants would need to adapt to this new approach, gathering their own evidence and presenting it to the courts. All of these changes, however, are feasible.

\section{Percolating Procedure and Jurisdiction}

As all of the above demonstrates, interlocutory appeals might be one context in which a little percolation-like judicial experimentation is not only feasible but also beneficial. This raises an interesting question as to whether similar experimentation would benefit other procedural and jurisdictional issues. Recall the reasons why percolation might work well in the interlocutory appeals context: the courts of appeals would have the ability to monitor and use evidence about the consequences of different rules, and a conflict over the availability of an interlocutory appeal likely has a smaller effect on prelitigation behavior than a conflict over substantive law. ${ }^{170}$ Similar arguments might apply to other procedural and jurisdictional areas; courts can generally

${ }^{167}$ Id.

168 Id.

${ }^{169} \mathrm{Id}$. at 608 .

${ }^{170}$ See supra Part III.A. 
monitor the effect of procedural and jurisdictional rules on litigation within their jurisdiction, and many procedural rules probably have only minor effects on pre-litigation behavior.

Commentators have addressed the propriety of percolation in procedure and jurisdiction only in passing. ${ }^{171}$ It seems, though, that the categories of "procedure" and "jurisdiction" are too broad to deem percolation generally appropriate or inappropriate; the costs and benefits of percolation likely vary from issue to issue. Thus, a jurisdictional rule that apportions work among the federal courts could be a good candidate for percolation. Apportioning work among the federal courts could involve largely administrative issues that federal courts are well equipped to handle. But a jurisdictional rule that apportions work between federal and state courts might not be a good subject for judicial experimentation. ${ }^{172}$ Deciding whether a case should be in federal or state court involves considerations of federalism on which courts have neither expertise nor any way to monitor the effects of different rules.

Some issues in procedure and jurisdiction thus might benefit from some judicial experimentation. Indeed, judicial experimentation might be one way to bring some lessons of experience to procedure and jurisdiction-areas that are sometimes criticized for lacking common sense ${ }^{173}$-while also providing some of the flexibility needed to accommodate the ever-changing world of litigation. Experimentation's propriety will depend on context, however, and exploring these contexts could be a fruitful area of future research.

\section{CONCLUSION}

Modern litigation is sometimes criticized for dealing too much in abstractions, conceptualizations, and conjecture rather than evidence about

171 Compare Estreicher \& Sexton, supra note 76, at 727 ("[T]here may be situations in which the Court would wish to encourage circuit-by-circuit experimentation, as in matters of trial procedure, where the primary conduct of litigants is not affected and the Court can observe the practical effects of varying legal rules."), with Mary Garvey Algero, A Step in the Right Direction: Reducing Intercircuit Conflicts by Strengthening the Value of Federal Appellate Court Decisions, 70 TENN. L. REV. 605, 614-15 (2003) (arguing that percolation "is not the best way to interpret and enforce 'federal' law, especially procedural law and statutory law").

${ }^{172}$ Cf. Gene R. Shreve, Pragmatism Without Politics-A Half Measure of Authority for Jurisdictional Common Law, 1991 BYU L. REv. 767 (arguing that federal court discretion over subject matter jurisdiction is appropriate when apportioning work among the federal courts but not when apportioning work between federal and state courts).

${ }^{173}$ Chief Judge Frank H. Easterbrook has perhaps made this point most plainly; when a lawyer at oral argument appealed to common sense in arguing for federal subject matter jurisdiction over a case, Judge Easterbrook responded, "You don't want to appeal to common sense about federal jurisdiction.... There's no overlap between the world of common sense and the world of federal jurisdiction. None whatsoever." Oral argument at 18:32, Bennett v. Sw. Airlines Co., 484 F.3d 907 (7th Cir. 2007), available at http://media.ca7.uscourts.gov/sound/2007/migrated.aims.06-3486_04_05_2007.mp3. 
actual social, political, economic, or any other kind of consequences. ${ }^{174}$ And in many contexts, "evidence-based law remains a dream." 175 But there are at least some contexts in which means exist to learn about consequences without substantial countervailing costs.

This Article shows that jurisdiction over interlocutory appeals is one such context. The debate over how to reform the regime of interlocutory appeals has long occurred at too abstract a level. Judicial experimentation, particularly through the use of a more standard-like collateral order doctrine, could bring to the discussion some evidence about the actual consequences of different appellate rules.

${ }^{174}$ See, e.g., Doe ex rel. Doe v. Elmbrook Sch. Dist., 687 F.3d 840, 878 (7th Cir. 2012) (en banc) (Posner, J., dissenting) ("[ []]sn't it about time that constitutional cases were decided on the basis of evidence rather than conjecture ('everyone knows') and doubtless in many cases bias?").

175 Id. at 873 . 
